\title{
REVIEW
}

\section{Insights into nanoparticle-induced changes in plant photosynthesis}

\author{
M. GHORBANPOUR ${ }^{*+}$, A. MOVAHEDI ${ }^{*}$, M. HATAMI $^{*}$, K. KARIMAN $^{* *}$, F. BOVAND ${ }^{* * *}$, \\ and M.A. SHAHID ${ }^{\#,+}$ \\ Department of Medicinal Plants, Faculty of Agriculture and Natural Resources, Arak University, \\ 38156-8-8349 Arak, Iran* \\ UWA School of Agriculture and Environment, The University of Western Australia, Perth, WA, 6009, Australia** \\ Departments of Agronomy, Islamic Azad University, Arak Branch, Arak, Iran ${ }^{* * *}$ \\ Department of Agriculture, Nutrition and Food Systems, University of New Hampshire, Durham NH 03824, USA
}

\begin{abstract}
Photosynthesis can be affected by nanoparticles (NPs) both negatively (e.g., through decreasing the chlorophyll content and electron transport rate, damages to chloroplast components, etc.) or positively (e.g., via enhancing chlorophyll content, the activity of Rubisco enzyme, the performance of PSII, and $\mathrm{CO}_{2}$ harvesting, as well as broadening the chloroplast photoabsorption spectrum). Enhanced photosynthetic efficiency could be a possible impact of NPs on photosynthetic organisms of major economic and ecological significance (e.g., crops and algae), which warrants an in-depth understanding of NPs interactions with chloroplast and its structural components (e.g., thylakoid membranes), signaling molecules, and pathways involved in photosynthesis. In this review, we comprehensively explore the potential effects of NPs on photosynthesis in different photosynthetic organisms (terrestrial plants, aquatic plants, and algae), and highlight research limitations and possible practical implications.
\end{abstract}

Keywords: chlorophyll; chloroplast; nanoparticles; photosynthesis.

\section{Introduction}

Nanus is a Greek word that means 'dwarf' and it is the base of the term 'nano' (Johal and Johnson 2018, Baker et al. 2019). When we divide a meter into 100 billion parts $\left(10^{-9}\right)$, we encounter a new scale, which is referred to as nanoscale (El Naschie 2006). Nanotechnology is a technology that uses nanoscale in at least one dimension (Gogotsi 2006), and it has applications in various industries, such as medicine, agriculture, environment, pharmaceutical, and food industries (Gade et al. 2010, Hatami and Ghorbanpour 2014, Singh et al. 2017, Tian et al. 2018, Fahimirad et al. 2019, Hatami et al. 2019a, Rahayu et al. 2020, Sharifi-Rad et al. 2021). Nanoparticles (NPs) are important because of their physical, chemical, and magnetic properties as well as being cheap, safe, and clean (El Naschie 2006, Gade et al. 2010, Johal and Johnson 2018). 'Dimension' is one of the main properties of the NPs, however, some NPs have no dimensions such as quantum dots and carbon dots. The dimensional NPs could possess one dimension (nanowires), two dimensions (nanofilms), or three dimensions (metal NPs) (Baker et al. 2019). There are three types of NPs depending on their origin: (1) natural NPs, originated from volcano eruptions,

\section{Highlights}

- Photosynthesis can be affected by nanoparticles (NPs) both positively and negatively

- NPs augment plant light-harvesting ability in a dose-dependent manner

- NPs-promoted photosynthetic efficiency may arise from the upregulation of key enzymes
Received 1 July 2021

Accepted 12 October 2021

Published online 8 November 2021

${ }^{+}$Corresponding authors

e-mail: m-ghorbanpour@araku.ac.ir Muhammad.shahid@unh.edu

Abbreviations: CdS - carbon quantum dots; $\mathrm{CeO}_{2}$ - cerium oxide; Chl - chlorophyll; MWCNT - multi-walled carbon nanotube; NPs - nanoparticles; SWCNT - single-walled carbon nanotube; $\mathrm{TiO}_{2}$ - titanium dioxide.

Conflict of interest: The authors declare that they have no conflict of interest. 
(2) incidental NPs, produced by human activities unintentionally, and (3) engineered NPs, produced to be used in different industries, agriculture, etc. (Večeřová et al. 2016). All these NPs can affect plants, mainly through their interactions with key cell organelles such as chloroplasts and mitochondria (Pagano et al. 2018). Quantum dots and NPs are wildly used in agriculture.

According to Das et al. (2017), plants harvest almost 100 TW (terawatts) of solar energy annually, which is ten times higher than human consumption. Since NPs have the potential to increase the solar energy harvest by plants, nanotechnology may revolutionize agriculture in the future. Nanotechnology has been used to produce genetically manipulated (GM) products (El Naschie 2006, Večeřová et al. 2016). Nanotechnology has also been used as a tool for sustainable productivity and protection of food/feed crops (Baker et al. 2019). Nanotechnology can make agricultural production better or worse by affecting the photosynthetic activities of plants (Djanaguiraman et al. 2018, Tombuloglu et al. 2019). The nature and magnitude of the impacts of NPs on photosynthesis depend on concentration, size, surface charge as well as the physicochemical properties of NPs, size of cell wall pores, plant species, and also the culture bed (Pagano et al. 2018, Tighe-Neira et al. 2018, Tan et al. 2019, Verma et al. 2019, Falco et al. 2020). Furthermore, the duration of the exposure between NPs and plant tissues may also be important. For example, Chlamydomonas reinhardtii (a single-cell green alga) cultures that were treated with $\mathrm{TiO}_{2}$ NPs for $8 \mathrm{~h}$ did not differ significantly in comparison with the untreated controls, whereas 12-h exposure stimulated their growth (Chen et al. 2012).

The size of NPs is another factor associated with their effects on plants. Small $\mathrm{TiO}_{2} \mathrm{NPs}(50 \mathrm{~nm})$ had a significant positive effect on the chlorophyll $(\mathrm{Chl})$ content of okra (Abelmoschus esculentus) plants, while the larger $\mathrm{TiO}_{2}$ NPs $(68 \mathrm{~nm})$ inhibited photosynthesis (Ogunkunle et al. 2020). When NPs are absorbed through the plasma membrane, they attach to proteins forming a complex called protein corona, which enters the neighboring cells via plasmodesmata channels (Hatami et al. 2016). Although NPs are in nanoscale, they must be small enough to pass through different barriers, such as cell walls, cell membrane, Casparian strip, cuticle, etc. (Večeřová et al. 2016, Tombuloglu et al. 2019). For example, NPs should be between $5-20 \mathrm{~nm}$ to be able to penetrate the cell wall pores (Hatami et al. 2016, Večeřová et al. 2016).

Nanoparticles can affect different processes of photosynthesis, or even in different parts of chloroplasts. In other words, NPs may affect the morphology of photosynthetic structures, contents of photosynthetic pigments, etc. (Tan et al. 2019). For example, NPs can increase the photosynthetic rate by enhancing the activity of Rubisco (Hussain et al. 2019, Kataria et al. 2019). Nanoparticles can also alter the performance of PSII and $\mathrm{CO}_{2}$ harvesting (Falco et al. 2020). Some NPs may decrease the absorption of sunlight by decreasing the Chl contents of plants (Tao et al. 2015). As photosynthetic rate depends on the Chl contents of plants, decreased Chl contents can negatively affect the photosynthetic rate (Wang et al. 2018).
Some NPs can change the wavelength domains of photosynthesis. For example, carbon dots (CDs) nanocapsules absorb wavelengths between 200-700 nm, which can increase the light harvest and also electron transport chain performance in PSII, and ultimately promote photosynthesis (Chandra et al. 2014, Verma et al. 2019, Xu et al. 2020). Interestingly, NPs may also act as a shadow, preventing light harvesting in plants, which is referred to as the 'shading effect'. As a result, plants start producing more Chl to harvest more light, however, they usually cannot afford it, leading to a decrease in photosynthesis (Middepogu et al. 2018). Hence, plants can be affected by NPs in different ways. Due to the significance of photosynthesis for plants and human life, it is vital to investigate NPs-plant interactions and their impact on photosynthesis. In this review, we mechanistically explore the effects of different NPs on photosynthesis and photosynthetic pigments in a broad range of photosynthetic organisms.

\section{Engineered nanoparticles}

Engineered NPs can change diverse metabolic pathways in plants including transpiration, gas exchange, biosynthesis and composition of pigments (e.g., Chl), and expression of photosynthesis-related genes (Tan et al. 2019). Here, we categorize engineered NPs into three main groups including (1) nanocarbons, which are made of carbon, (2) metal NPs, which include different kinds of metals and metal oxide compounds, and (3) magnetic NPs, which are metal NPs with magnetic properties.

\section{The entry and interaction pathways of NPs in plants through roots and leaves}

To deeply understand the nature of NPs-plant interactions, it is necessary to characterize the entry, uptake, translocation, accumulation, biotransformation, and fate of NPs within plant cells, tissues, and organelles. Entry and translocation of NPs can occur through root to shoot (down-top) or shoot to root (top-down) routes, an important feature that makes both foliar and soil applications feasible in agroecosystems. The entry (Fig. 1A) and interaction pathways of NPs in plants through leaves (Fig. $1 B$ ) and roots (Fig. 1C), and their long-distance transport via xylem and phloem (Fig. 1D), as well as their possible routes of cellular uptake (Fig. 1E) were schematically illustrated in Fig. 1. When applied to the foliage, NPs penetrate leaves through cuticles, stomatal openings, hydathodes, lenticels, trichomes, and wounds. NPs may undergo long-distance transport via the vascular systems, such as xylem and phloem conductive tissues, after entering the leaf apoplast through the aforementioned routes. When exposed to plant roots, NPs can penetrate via root tip, root hairs, lateral roots, rhizodermis, and rupture. As shown, when NPs are available either in culture medium or soil matrix, they can be transferred via both symplastic and apoplastic pathways to penetrate the root epidermis, pass through the cortex, and finally translocate and distribute to the aerial parts of plants including stems and leaves via the xylem and 


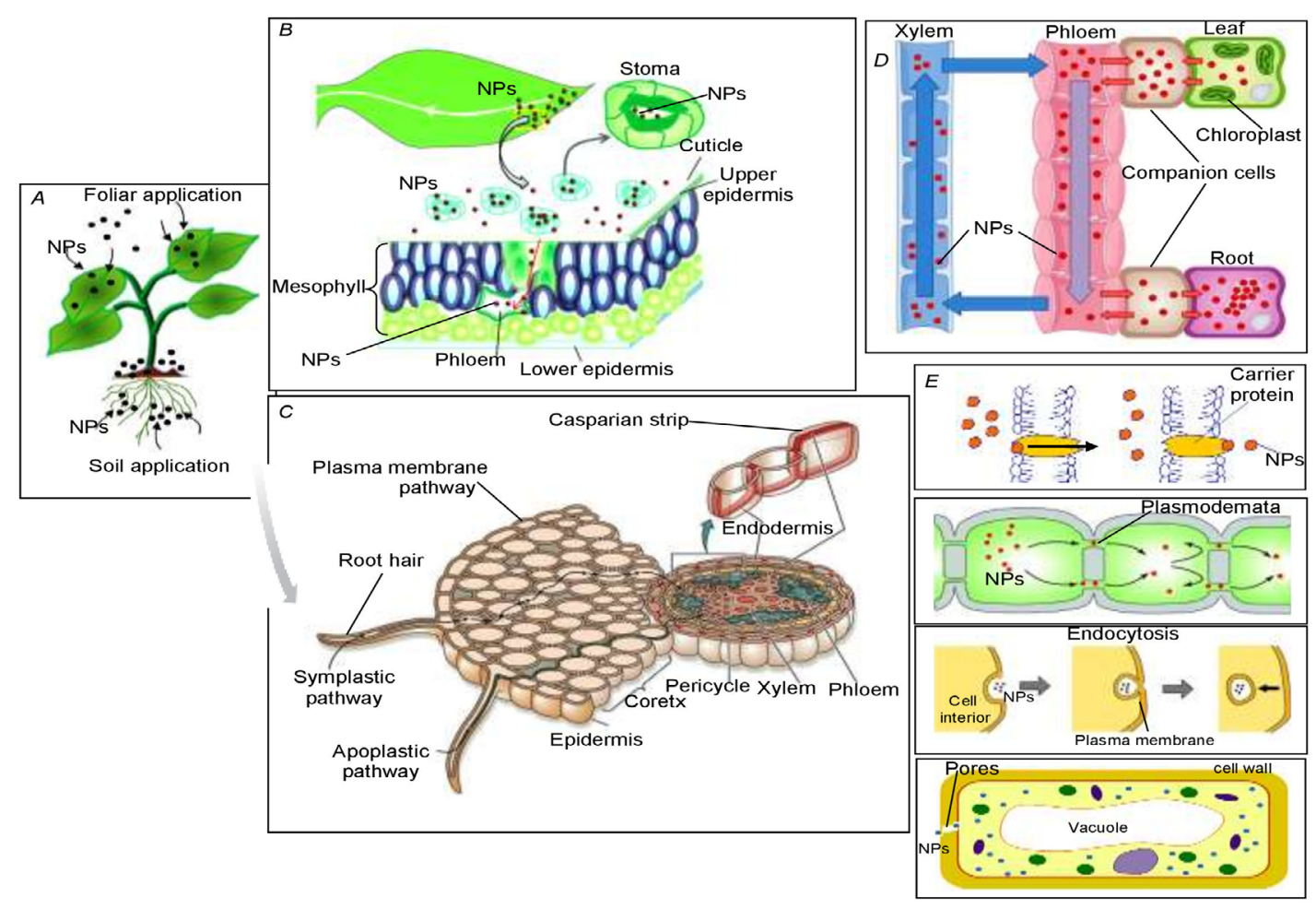

Fig. 1. The entry $(A)$ and interaction pathways of nanoparticles (NPs) in plants through roots and leaves $(B$ and $C)$. Long-distance NPs transport via xylem and phloem $(D)$. Probable routes of cellular uptake of the NPs in the plant cell $(E)$.

phloem vessels. The absorbed NPs via the foliage could be redistributed to other plant organs such as roots through the phloem. There are several routs for NPs to enter the symplastic pathway such as endocytosis (Etxeberria et al. 2006), pore formation (Serag et al. 2011, Wong et al. 2016), carrier proteins (Rico et al. 2011, Schwab et al. 2015), plasmodesmata (Zhai et al. 2014) and ion channels (Perez-de-Luque 2017). Several factors affect the plant uptake of NPs such as physicochemical characteristics of NPs, plant species type, plant growth/physiological stage, root exudates, soil properties $(\mathrm{pH}$, organic matter, salt ions, and microflora), etc.

\section{Nanocarbons}

Carbon dots (CDs) are one type of nanocarbons, which function as electron donors and acceptors, so they can influence electron transportation positively (Wang et al. 2018, Xu et al. 2020). In PSI, Fe-S proteins act as the carriers of electrons. Wang et al. (2018) declared that CDs can attach to these proteins and accelerate electron transport (Wang et al. 2018). Exposure to $>0.02 \mathrm{mg}$ (CDs) $\mathrm{mL}^{-1}$ led to a positive impact on the growth of mung bean sprouts, which could be attributed to enhanced electron transport (Wang et al. 2018). Carbon dots can also affect Chl contents, photosynthesis, and the Rubico activities of plants (Wang et al. 2018). Spraying 3,900 $\mathrm{mg} \mathrm{L}^{-1}$ of CDs nanocapsules significantly increased the photosynthetic rate of Lactuca sativa (Xu et al. 2020). The Chl pigments in Lablab purpureus plants were shown to absorb more light via increasing the concentration of carbon NPs, and application of $1.2-2.5 \mathrm{mg} \mathrm{mL}^{-1}$ of carbon NPs led to the maximum light absorption (Swapna et al. 2019). Carbon dots may also influence plants negatively. For example, the application of CDs decreased the activities of photosynthetic enzymes in Arabidopsis thaliana (Chen et al. 2018). Carbon nanotubes (CNTs) increased the number of stomata, electron transport rate, and ultimately the photosynthetic rate in rice (Joshi et al. 2020). These CNTs caused an increase in Chl content and leaf surface area of tobacco (Mahto et al. 2019).

Single-walled carbon nanotubes (SWCNTs) and multiwalled carbon nanotubes (MWCNTs) are two kinds of CNTs that can positively affect plant metabolism and photosynthesis (Ghorbanpour and Hadian 2015, Hatami et al. 2017, Samadi et al. 2020, 2021). The SWCNTs absorb a wide range of light, including ultraviolet, visible light, and infrared, which can promote photosynthesis (Giraldo et al. 2014, Wang et al. 2020). The electron transport from PSII to PSI can also be improved by SWCNTs (Gong and Zhao 2018). The photosynthetic activities were tripled in Arabidopsis thaliana plants subjected to SWCNTs (Giraldo et al. 2014). Similar effects have been documented for MWCNTs. Rice plants exposed to MWCNTs (70, 80, and $90 \mathrm{mg} \mathrm{mL}^{-1}$ ) had increased total Chl contents (Joshi et al. 2020). Likewise, MWCNTs application at concentrations of $0.1,0.25$, and $0.5 \mathrm{~g} \mathrm{~L}^{-1}$, caused an increase in the Chl concentration of 
amaranth plants (Jia et al. 2019). MWCNTs application (>50 $\mathrm{mg} \mathrm{L}^{-1}$ ) was shown to increase light absorption, along with photosynthetic rate and function in Arabidopsis thaliana (Fan et al. 2018). Adverse effects have also been established in plants subjected to MWCNTs. Application of MWCNTs at $100 \mathrm{mg} \mathrm{L}^{-1}$ had no significant effect on carrot seedlings, whereas a higher concentration $(200 \mathrm{mg}$ $\mathrm{L}^{-1}$ ) led to a $10 \%$ reduction in the growth of the seedlings (Park and Ahn 2016).

Graphene NPs are another important type of carbon-based NPs that have agricultural applications (Ghorbanpour et al. 2018, Hatami et al. 2019b). Capsicum annuum plants exposed to graphene nanosheets showed an elevated photosynthetic rate (Younes et al. 2019). Also, $0.4 \mathrm{mg} \mathrm{L}^{-1}$ of graphene oxide (GO) NPs decreased the Chl content of pea plants (Chen et al. 2019). GO NPs can also decrease light absorption in plants (Nogueira et al. 2015). Fullerenols (C60) NPs are another type of nanocarbon material, which were demonstrated to increase the Chl content in wheat (Wang et al. 2016). Approximately, half of the global photosynthesis occurs in aquatic ecosystems, hence, it is crucial to investigate the effects of different NPs on photosynthetic organisms inhabiting these ecosystems (Zhang et al. 2017). Carbon dots (CDs) were demonstrated to promote the productivity of microalgal species including Haematococcus pluvialis (5, $\left.10 \mathrm{mg} \mathrm{mL}^{-1}\right)$ and Chlorella sp. KR-1 (5 mg mL $\left.\mathrm{mL}^{-1}\right)$, whereas a higher CDs concentration $\left(50 \mathrm{mg} \mathrm{mL}^{-1}\right)$ decreased the growth rate of Chlorella vulgaris (Choi et al. 2020). Graphene oxide NPs, at $1 \mathrm{mg} \mathrm{L}^{-1}$, were shown to adversely affect the growth of the freshwater plant Lemna minor (Hu et al. 2018). The Chl content decreased in the microalga Raphidocelis subcapitata exposed to GO NPs (Nogueira et al. 2015). Upon exposure to C60 NPs, Chl $a$ and Chl $b$ contents decreased in Lemna gibba (2 $\mathrm{mg} \mathrm{L}^{-1}$ ) and Scenedesmus obliquus (>0.18 $\mathrm{mg} \mathrm{L}^{-1}$ ) (Santos et al. 2013, Tao et al. 2015).

\section{Metal/metal oxide nanoparticles}

Although most metal NPs may harm plants, some metal oxide NPs can improve the production of chemical energy in photosynthetic systems. Some metal-based NPs, such as $\mathrm{CuO}, \mathrm{ZnO}$, and $\mathrm{Ag} \mathrm{NPs}$, may disrupt Chl biosynthesis, however, some other NPs, e.g., $\mathrm{TiO}_{2}$ and $\mathrm{Au} \mathrm{NPs}$, were shown to increase the Chl content in several plant species (Večeřová et al. 2016). Metal NPs can also increase the Chl content of plants, helping them absorb more energy and consequently enhance their photosynthesis (Wang et al. 2018, Kataria et al. 2019).

\section{Titanium dioxide nanoparticles $\left(\mathrm{TiO}_{2} \mathrm{NPs}\right)$}

$\mathrm{TiO}_{2}$ NPs possess a high capability in increasing light absorption (especially UV light), photosynthesis, electron transport, and also protecting Chl molecules (Park and Ahn 2016, Morelli et al. 2018, Mahto et al. 2019, Faraji and Sepehri 2020). However, $\mathrm{TiO}_{2}$ NPs may affect various plants differently (Hatami et al. 2014). For example, $\mathrm{TiO}_{2}$ NPs can disrupt electron transport to PSII and their effect depends on the application/uptake type and also the plant species (Conway et al. 2015). Yang et al. (2007) evaluated the effects of $\mathrm{TiO}_{2} \mathrm{NPs}(0.25 \%)$ on the oxygen evolution of spinach leaves and found that exposure to $\mathrm{TiO}_{2} \mathrm{NPs}$ and their bulk significantly enhanced the oxygen-evolving rate. However, the oxygen evolution was restrained in plants grown under $\mathrm{N}$-deficient conditions. Moreover, the oxygen-evolving rate in plants exposed to $\mathrm{TiO}_{2} \mathrm{NPs}$ was much higher than bulk $\mathrm{TiO}_{2}$-treated and untreated controls under such conditions, representing that application of $\mathrm{TiO}_{2} \mathrm{NPs}$ may intensely ameliorate the adverse impacts of $\mathrm{N}$-deficiency on the oxygen evolution of plants. Increased oxygen-evolution rate in leaves following exposure to $\mathrm{TiO}_{2}$ NPs was attributed to the improved light absorption and photochemical reaction activity (Yang et al. 2007), which is consistent with enhancement of chlorophyll synthesis and sensitization of $\mathrm{TiO}_{2} \mathrm{NPs}$ in chloroplasts (Gao et al. 2006). Both $\mathrm{TiO}_{2}$ NPs and bulk $\mathrm{TiO}_{2}$ may enhance plastid pigments of chloroplasts to absorb and transfer light energy and excite electrons, causing water photolysis (Hong et al. 2005).

Generally, the application of Ti not only improved soybean photosynthesis by increasing leaf area and leaf chlorophyll contents, but also increased shade tolerance and yield of soybean under maize-soybean relay strip intercropping conditions (Hussain et al. 2021). However, $\mathrm{TiO}_{2}$ NPs might have positive structural and biochemical effects on some crops, whereas they could harm other plant/algae species (Tighe-Neira et al. 2018). Furthermore, the positive effects of $\mathrm{TiO}_{2}$ NPs on plants are more pronounced as compared to the bulk $\mathrm{TiO}_{2}$, which is attributed to their size differences (Cox et al. 2016). Table 1 presents the effects of $\mathrm{TiO}_{2} \mathrm{NPs}$ on photosynthesis machinery in different plant/algal species.

\section{Silver nanoparticles (Ag NPs)}

Ag NPs are one of the most important NPs because of their antimicrobial properties and also their extensive use in care products, food industry, agriculture, building materials, etc. (Hatami and Ghorbanpour 2013, Qian et al. 2013, Hajian et al. 2022). Exposure to Ag NPs can lead to maximum absorption of visible light in certain plants (Wang et al. 2020). Ag NPs and $\mathrm{AgNO}_{3}$ NPs are two main types of Ag NPs, both of which were shown to significantly reduce the photosynthetic performance, total chlorophyll, carotenoids, and total protein content and also increased the oxidative stress in cucumber (Cucumis sativus); the adverse effects were greater in plants treated with $\mathrm{AgNO}_{3}$ NPs (Tripathi et al. 2017a). Likewise, exposure to $400 \mathrm{mg} \mathrm{L}^{-1}$ of $\mathrm{Ag} \mathrm{NPs}$ or $\mathrm{AgNO}_{3} \mathrm{NPs}$ led to significant reductions in the Chl contents and growth parameters in Brassica nigra, however, Ag NPs were demonstrated to be more toxic than $\mathrm{AgNO}_{3} \mathrm{NPs}$ as revealed by monitoring the $\mathrm{Ag}$ accumulation as well as the lipid peroxidation and the $\mathrm{H}_{2} \mathrm{O}_{2}$ content of root and shoot tissues (Amooaghaie et al. 2018).

Ag NPs, in low concentrations, are useful for improving the biosynthesis of $\mathrm{Chl}$ and $\mathrm{Chl}$ fluorescence parameters in plants (Ghorbanpour and Hatami 2014, 


\section{GHORBANPOUR et al.}

Table 1. The effects of $\mathrm{TiO}_{2}$ nanoparticles (NPs) on photosynthesis in different plant/algal species.

\begin{tabular}{|c|c|c|c|c|c|}
\hline Plant/algal species & NPs concentratio & n NPs size & Growth medium & Effects & Reference \\
\hline Zea mays & Not mentioned & Not mentioned & Not mentioned & $\begin{array}{l}\text { Increased in photosynthetic } \\
\text { pigments and light absorption }\end{array}$ & Park and Ahn (2016) \\
\hline Zea mays & $100 \mathrm{mg} \mathrm{kg}^{-1}$ & $592 \pm 7 \mathrm{~nm}$ & Soil & $\begin{array}{l}\text { No effect on Chl } a \text {, Chl } b \text {, } \\
\text { and carotenoids }\end{array}$ & Zhao et al. (2019) \\
\hline Zea mays & Not mentioned & $30.1-60 \mathrm{~nm}$ & Not mentioned & $\begin{array}{l}\text { Decreased in leaves growth } \\
\text { and transpiration rate }\end{array}$ & Mishra et al. (2014) \\
\hline $\begin{array}{l}\text { Dracocephalum } \\
\text { moldavica }\end{array}$ & $100 \mathrm{mg} \mathrm{L}^{-1}$ & Not mentioned & $\begin{array}{l}\text { Hydroponic } \\
\text { growth medium } \\
\text { containing } \\
\text { cocopit and perlit }\end{array}$ & $\begin{array}{l}\text { Increased in Chl } a, \mathrm{Chl} b \text {, } \\
\text { and carotenoids }\end{array}$ & Gohari et al. (2020) \\
\hline Mentha piperita & $100 \mathrm{mg} \mathrm{L}^{-1}$ & Not mentioned & Not mentioned & $\begin{array}{l}\text { Increased in essential oil } \\
\text { contents }\end{array}$ & Samadi et al. (2014) \\
\hline $\begin{array}{l}\text { Abelmoschus } \\
\text { esculentus (L.) } \\
\text { Moench }\end{array}$ & $800 \mathrm{mg} \mathrm{kg}^{-1}$ & $50 \mathrm{~nm}$ & Loamy soil & $\begin{array}{l}\text { Decreased in Chl } a, \mathrm{Chl} b \text {, } \\
\text { and total Chl content }\end{array}$ & Ogunkunle et al. (2020) \\
\hline Mentha piperita $\mathrm{L}$. & $150 \mathrm{mg} \mathrm{L}^{-1}$ & $<21 \mathrm{~nm}$ & $\begin{array}{l}\text { Pot, filled with } \\
\text { homogenous } \\
\text { mixture of soil } \\
\text { and organic manure }\end{array}$ & $\begin{array}{l}\text { Increased in Chl contents, } \\
\text { photosynthetic rate, } \\
\text { and Rubisco activity }\end{array}$ & Ahmad et al. (2018) \\
\hline $\begin{array}{l}\text { Petroselinum } \\
\text { crispum }\end{array}$ & $\begin{array}{l}10,000 ; 20,000 \\
30,000 ; \text { and } \\
40,000 \mathrm{mg} \mathrm{L}^{-1}\end{array}$ & $83.7 \mathrm{~nm}$ & $\begin{array}{l}\text { Murashige and } \\
\text { Skoog medium }\end{array}$ & Increased in $\mathrm{Chl}$ content & Hu et al. (2020) \\
\hline Spinacia oleracea & Not mentioned & Not mentioned & Not mentioned & $\begin{array}{l}\text { Chl formation, increasing in } \\
\text { Rubisco activity and } \\
\text { photosynthesis }\end{array}$ & Kataria et al. (2019) \\
\hline Spinacia oleracea & Not mentioned & Not mentioned & Not mentioned & $\begin{array}{l}\text { Increasing Chl content and } \\
\text { photosynthetic activities }\end{array}$ & Baker et al. (2019) \\
\hline Spinacia oleracea & Not mentioned & $5 \mathrm{~nm}$ & $\begin{array}{l}\text { Experimental } \\
\text { flower pot }\end{array}$ & $\begin{array}{l}\text { Increasing net photosynthetic } \\
\text { rate and accumulation of organic } \\
\text { substances and Rubisco activity }\end{array}$ & Gao et al. (2008) \\
\hline Spinacia oleracea & $0.25 \%$ & $5 \mathrm{~nm}$ & Not mentioned & $\begin{array}{l}\text { Damaging chloroplast and } \\
\text { decreasing photosynthesis }\end{array}$ & Missaoui et al. (2017) \\
\hline $\begin{array}{l}\text { Linum } \\
\text { usitatissimum }\end{array}$ & Not mentioned & Not mentioned & Not mentioned & $\begin{array}{l}\text { Increasing in } \mathrm{Chl} \\
\text { and carotenoid content }\end{array}$ & Kataria et al. (2019) \\
\hline $\begin{array}{l}\text { Lycopersicon } \\
\text { esculentum }\end{array}$ & Not mentioned & Not mentioned & Not mentioned & Increasing photosynthesis & Kataria et al. (2019) \\
\hline $\begin{array}{l}\text { Lycopersicon } \\
\text { esculentum }\end{array}$ & $0.05,0.1 \mathrm{~g} \mathrm{~L}^{-1}$ & $16.04 \mathrm{~nm}$ & $\begin{array}{l}\text { Nutrition pot } \\
\text { inside heated } \\
\text { solar greenhouse }\end{array}$ & $\begin{array}{l}\text { Enhanced net photosynthetic } \\
\text { rate }\end{array}$ & Qi et al. (2013) \\
\hline $\begin{array}{l}\text { Lycopersicon } \\
\text { esculentum }\end{array}$ & $0.2 \mathrm{~g} \mathrm{~L}^{-1}$ & $16.04 \mathrm{~nm}$ & $\begin{array}{l}\text { Nutrition pot } \\
\text { inside heated } \\
\text { solar greenhouse }\end{array}$ & $\begin{array}{l}\text { Decreased in net } \\
\text { photosynthetic rate }\end{array}$ & Qi et al. (2013) \\
\hline Ulmus elongata & Not mentioned & Not mentioned & Not mentioned & $\begin{array}{l}\text { Decreased in quantum } \\
\text { function of PSII and electron } \\
\text { transportation rate }\end{array}$ & Kataria et al. (2019) \\
\hline $\begin{array}{l}\text { Spirodella } \\
\text { polyrrhiza }\end{array}$ & $1,5,10 \mathrm{mg} \mathrm{l}^{-1}$ & $8 \mathrm{~nm}$ & $\begin{array}{l}\text { Glass aquaria, } \\
\text { a specific culture } \\
\text { medium }\end{array}$ & Decreased in total $\mathrm{Chl}$ content & Movafeghi et al. (2018) \\
\hline Lactuca sativa & $\begin{array}{l}1,10, \\
\text { and } 100 \mathrm{mg} \mathrm{L}^{-1}\end{array}$ & Not mentioned & Hydroponic & $\begin{array}{l}\text { No significant effect on plastid } \\
\text { pigments }\end{array}$ & Tan et al. (2019) \\
\hline $\begin{array}{l}\text { Clarkia } \\
\text { unguiculata }\end{array}$ & $100 \mathrm{mg} \mathrm{L}^{-1}$ & $27 \pm 4 \mathrm{~nm}$ & Soil & Disturbance in $\mathrm{CO}_{2}$ absorption & Cox et al. (2016) \\
\hline Chlorella vulgaris & Not mentioned & $25 \mathrm{~nm}$ & $\begin{array}{l}\text { Slightly modified } \\
\text { OECD algal } \\
\text { medium }\end{array}$ & Decreased in total $\mathrm{Chl}$ content & Dauda et al. (2017) \\
\hline Chlorella vulgaris & $\begin{array}{l}50,100,150 \\
\text { and } 200 \mathrm{ppm}\end{array}$ & Not mentioned & Not mentioned & $\begin{array}{l}\text { Hinder the photosynthetic } \\
\text { activities }\end{array}$ & Ghazaei and Shariati (2020) \\
\hline
\end{tabular}




\begin{tabular}{|c|c|c|c|c|c|}
\hline $\begin{array}{l}\text { Chlorella } \\
\text { ellipsoidea }\end{array}$ & $0.1 \mu \mathrm{g} \mathrm{L}^{-1}$ & $<21 \mathrm{~nm}$ & Algal medium & $\begin{array}{l}\text { Increased in Chl } a, \mathrm{Chl} b \text {, } \\
\text { and total Chl contents }\end{array}$ & Matouke et al. (2018) \\
\hline $\begin{array}{l}\text { Chlorella } \\
\text { pyrenoidosa }\end{array}$ & $20 \mathrm{mg} \mathrm{L}^{-1}$ & $12.0 \pm 3.5 \mathrm{~nm}$ & $\begin{array}{l}\text { Erlenmeyer } \\
\text { flasks }\end{array}$ & Increased in Chl $a$ content & Middepogu et al. (2018) \\
\hline Dunaliella salina & $\begin{array}{l}50,100,150 \\
\text { and } 200 \mathrm{ppm}\end{array}$ & Not mentioned & $\begin{array}{l}\text { Johnson modified } \\
\text { medium }\end{array}$ & $\begin{array}{l}\text { Decreased in Chl content } \\
\text { and photosynthesis efficiency }\end{array}$ & Ghazaei and Shariati (2020) \\
\hline $\begin{array}{l}\text { Dunaliella } \\
\text { tertiolecta }\end{array}$ & $\begin{array}{l}50,100,150, \\
\text { and } 200 \mathrm{ppm}\end{array}$ & Not mentioned & $\begin{array}{l}\text { Johnson modified } \\
\text { medium }\end{array}$ & $\begin{array}{l}\text { Decreased in Chl content } \\
\text { and photosynthesis efficiency }\end{array}$ & Ghazaei and Shariati (2020) \\
\hline $\begin{array}{l}\text { Dunaliella } \\
\text { tertiolecta }\end{array}$ & $0.1-10 \mathrm{mg} \mathrm{l}^{-1}$ & $25 \mathrm{~nm}$ & Algal medium & $\begin{array}{l}\text { No effect on photosynthetic } \\
\text { pigments }\end{array}$ & Morelli et al. (2018) \\
\hline
\end{tabular}

Sami et al. 2020). Exposure to Ag NPs at 20, 40, and $60 \mathrm{mg} \mathrm{L}^{-1}$ led to increased Chl contents in Zea mays and Phaseolus vulgaris, while higher concentrations (80 and $100 \mathrm{mg} \mathrm{L}^{-1}$ ) led to adverse effects on the Chl content (Salama 2012). Rubisco activities increased in tobacco plants treated with $\mathrm{Ag} \mathrm{NPs}$ and $\mathrm{AgNO}_{3} \mathrm{NPs}(25,50$, and $76 \mu \mathrm{M})$ (Tkalec et al. 2017). Similarly, Ag NPs increased the Chl contents in carrots (Park and Ahn 2016). Likewise, a dose-dependent effect was observed in Brassica juncea plants exposed to Ag NPs, i.e., 25, 50, and $100 \mathrm{mg} \mathrm{L}^{-1}$ of Ag NPs, increased the Chl contents and PSII efficiency, whereas these parameters decreased by higher Ag NPs concentrations of 200 and $400 \mathrm{mg} \mathrm{L}^{-1}$ (Sharma et al. 2012). Ag NPs also increased the $\mathrm{Chl}$ and carotenoid contents in Pelargonium zonale (Kataria et al. 2019). Moreover, exposure to Ag NPs increased the Chl content and quantum efficiency in Brassica juncea (Torrent et al. 2020). Treatment with $25-50 \mathrm{mg} \mathrm{L}^{-1}$ of Ag NPs enhanced the number of shoots per explant, shoot height, and Chl content in micropropagation of vanilla plants in temporary submerged systems (Spinoso-Castillo et al. 2017).

Ag NPs can also affect photosynthesis negatively. Here, we briefly mention several examples of negative Ag NPs-plant interactions. A high concentration of $\mathrm{Ag}$ and $\mathrm{Ag}^{+} \mathrm{NPs}\left(0.5\right.$ and $\left.3 \mathrm{mg} \mathrm{L} \mathrm{L}^{-1}\right)$ decreased the Chl contents in $A$. thaliana (Qian et al. 2013). The negative effects of $\mathrm{Ag}^{+}$are generally more than $\mathrm{Ag}$ NPs (Qian et al. 2013). Exposure to 1,000 and 3,000 $\mu \mathrm{M}$ of Ag NPs decreased growth parameters, photosynthetic pigments, and Chl fluorescence in Pisum sativum (Tripathi et al. 2017b). Ag NPs caused an overproduction of reactive oxygen species (ROS) in the leaves of cucumber plants, leading to decreased photosynthetic activities (Wang et al. 2020). ROS directly damage chloroplasts in stressed plants (Tripathi et al. 2017c). The acceptor site of PSI in the chloroplast has been found as a major source of free radicals (ROS), which are responsible for the oxidative damage-induced reduction in photosynthetic activity and destruction of photosystems as well as improper regulation of PSI electron transport in wheat seedlings exposed to AgNPs (at $5 \mathrm{mM}$ ) (Rastogi et al. 2019b). Ag NPs reduced the rate of electron transport chain, $\mathrm{CO}_{2}$ absorption, and the photochemical efficiency of PSII, while causing an increase in the nonphotochemical quenching in Vicia faba plants (Falco et al. 2020). Application of Ag NPs led to decreased transpiration in Cucurbita pepo (Mishra et al. 2014). The concentrations of Chl $a$ and Chl $b$ decreased in Brazilian waterweed (Egeria densa) upon exposure to Ag NPs (Winkelmann et al. 2017). Treatments with Ag NPs (20-50 $\mathrm{mg} \mathrm{L}^{-1}$ ) harmed mung plants and decreased their total Chl contents (Mahto et al. 2019). Application of Ag NPs (10-15 nm) at high concentrations (> $500 \mathrm{mg}$ $\left.\mathrm{L}^{-1}\right)$ significantly decreased the $\mathrm{Chl}$ contents in tomato plants (Pagano et al. 2018). In rice, Ag NPs (0.2, 0.5, and $1 \mathrm{mg} \mathrm{L}^{-1}$ ) decreased the total $\mathrm{Chl}$ and carotenoid contents (Nair and Chung 2014). A decrease in maximum electron transport rate was observed in Vicia faba plants subjected to Ag NPs (Falco et al. 2020). Inhibition of photosynthetic pathways was observed in A. thaliana plants treated with 0.5 and $1 \mathrm{mg} \mathrm{L}^{-1}$ of Ag NPs (Cox et al. 2016). Both Ag and $\mathrm{AgNO}_{3}$ NPs were demonstrated to have a negative impact on $\mathrm{Chl} a, \mathrm{Chl} b$, and carotenoid contents in tobacco seedlings, however, the magnitude of the negative effects was greater in plants subjected to $\mathrm{AgNO}_{3}$ NPs (Peharec Štefanić et al. 2018). Likewise, both $\mathrm{Ag}$ and $\mathrm{AgNO}_{3} \mathrm{NPs}$ significantly decreased the Chl content and photosynthesis in Cucumis sativus (Tripathi et al. 2017a).

Generally, Ag NPs that are coated with PVP, PEG or citrate, display reduced phytotoxicity (Torrent et al. 2020). Exposure of Ag NPs-citrate (Ag NPs coated with citrate) had no significant effect on Chl contents of Physcomitrella patens, whereas Ag NPs-PVP [coated with poly(N-vinyl2-pyrrolidone)] increased the $\mathrm{Chl} a$ content in these plants (Liang et al. 2018). However, Chl $a$ and Chl $b$ contents of these plants significantly reduced upon exposure to Ag NPs without surface coating (Liang et al. 2018). Although both Ag NPs and Ag NPs-PVP decreased the transpiration rate and stomatal conductance in Lactuca sativa, the negative effects of Ag NPs-PVP were lesser than that of the uncoated Ag NPs. Similar to terrestrial plants, Ag NPs may cause negative or positive effects on aquatic plants and algae. Application of Ag NPs decreased the Chl content and PSII function of the marine diatom Skeletonema costatum (Tighe-Neira et al. 2018). A low concentration of Ag NPs $\left(0.05 \mathrm{mg} \mathrm{L}^{-1}\right)$ increased the Chl $a$ content, whereas a higher Ag NPs concentration $\left(5 \mathrm{mg} \mathrm{L}^{-1}\right)$ decreased the Chl contents in $S$. costatum (Huang et al. 2016). Treatment with Ag NPs, at 40-50 mg L ${ }^{-1}$, reduced the electron transportation from $\mathrm{Q}_{\mathrm{A}}$ to $\mathrm{Q}_{\mathrm{B}}$ in PSII in the green alga Chlamydomonas (Nam et al. 2018). Application of both $\mathrm{Ag}$ and $\mathrm{AgNO}_{3} \mathrm{NPs}$ led to a negative effect on the photosynthesis efficiency of Euglena gracilis (freshwater single-celled alga) (Li et al. 2015). Ag NPs (10 $\left.\mu \mathrm{g} \mathrm{L}^{-1}\right)$ also decreased the total $\mathrm{Chl}$ content in the green eukaryotic 
microalga Chlorella vulgaris (Tayemeh et al. 2020). Ag NPs (1-10 $\left.\mathrm{mg} \mathrm{L}^{-1}\right)$ increased the Chl content in the aquatic flowering plant Eichhornia crassipes (Rani et al. 2016).

\section{Zinc oxide nanoparticles (ZnO NPs)}

Zinc oxide $(\mathrm{ZnO}) \mathrm{NPs}$ are one of the most important NPs, because of their large surface area, low toxicity, and especially their unique physicochemical properties (Baker et al. 2019). A broad range of studies has shown that $\mathrm{ZnO}$ NPs may promote or disrupt photosynthesis (Table 2). For example, when Anabaena sp. plants were exposed to $\mathrm{ZnO}$ NPs, their photosynthesis and other metabolic activities were adversely affected (Tang et al. 2015). Other Zn NPs such as $\mathrm{ZnS}$ NPs also affect photosynthesis. For example, 125, 250, and $500 \mathrm{mg} \mathrm{L}^{-1}$ of ZnS NPs decreased the Chl content in pea plants, whereas these NPs increased the Chl content in mung beans compared to controls (Thapa et al. 2019). Enhanced Chl and/or carotenoid contents have been observed in different plant species subjected to $\mathrm{ZnO}$ NPs including Solanum lycopersicum (Singh et al. 2016), Coriandrum sativum (Pullagurala et al. 2018), and Cucumis sativus (Kataria et al. 2019).

\section{Cerium oxide nanoparticles $\left(\mathrm{CeO}_{2} \mathrm{NPs}\right)$}

Cerium oxide is one of the most important nanoceria. $\mathrm{CeO}_{2}$ can penetrate the leaf cells and also penetrate chloroplasts as well as thylakoids, which can suppress electron transportation to PSII (Conway et al. 2015). The application of $\mathrm{CeO}_{2}$ NPs decreased the photosynthetic rate by reducing the $\mathrm{Chl}$ content in wheat (Wang et al. 2016). Exposure to $200 \mathrm{mg} \mathrm{kg}^{-1} \mathrm{CeO}_{2} \mathrm{NPs}$ significantly decreased the photosynthetic rate and transpiration in Cucumis sativus (Tan et al. 2019). Treatment with 1,000$2,000 \mathrm{mg} \mathrm{kg}^{-1}$ of $\mathrm{CeO}_{2}$ NPs also decreased the Chl content in Lactuca sativa (Lizzi et al. 2019). Likewise, $\mathrm{CeO}_{2} \mathrm{NPs}$ caused a decrease in photosynthesis in Clarkia unguiculata (Conway et al. 2015) and Cucumis sativus (Tighe-Neira et al. 2018). However, as we mentioned previously, NPs concentration and plant species are key players of the net outcome arising from NPs-plant interactions (TigheNeira et al. 2018, Abbas et al. 2020). For example exposure to $2,000 \mathrm{mg} \mathrm{L}^{-1}$ of $\mathrm{CeO}_{2} \mathrm{NPs}$ decreased the Chl content, plant growth, and photosynthesis in wheat, however, treatment with $1,000 \mathrm{mg} \mathrm{L}^{-1}$ of $\mathrm{CeO}_{2} \mathrm{NPs}$ was accompanied by the maximum photosynthetic rate, along with enhanced $\mathrm{CO}_{2}$ assimilation quantum yield $\left(\varphi_{\mathrm{CO} 2}\right)$ and stomatal conductance (Abbas et al. 2020). $\mathrm{CeO}_{2} \mathrm{NPs}$ may also cause a deformation in photosynthetic tissues. For example, wheat plants exposed to $\mathrm{CeO}_{2}$ NPs (100 and $400 \mathrm{mg} \mathrm{kg}^{-1}$ ) had swollen chloroplasts (Tan et al. 2019). Lower concentrations of $\mathrm{CeO}_{2}$ NPs can have a positive effect on photosynthesis (Abbas et al. 2020). Treatment with $300 \mathrm{mg} \mathrm{L}^{-1}$ of $\mathrm{CeO}_{2}$ NPs increased the Chl content, net photosynthetic rate, and Rubisco activity in Fragaria ananassa (Dai et al. 2020). The application of $\mathrm{CeO}_{2} \mathrm{NPs}$ can increase the uptake of $\mathrm{Mg}^{2+}$ ions, which are a key structural component of the Chl molecule. For instance, the application of $400 \mathrm{mg} \mathrm{kg}^{-1}$ of $\mathrm{CeO}_{2}$ NPs increased photosynthesis in cucumber plants via increasing their $\mathrm{Mg}^{2+}$ uptake (Rossi et al. 2016). An increase in the Chl content and photosynthesis efficiency occurred when Brassica napus L. plants were subjected to $200 \mathrm{mg} \mathrm{kg}^{-1}$ of $\mathrm{CeO}_{2}$ NPs (Zhao et al. 2020). Treatment with $500 \mathrm{mg} \mathrm{L}^{-1}$ of $\mathrm{CeO}_{2}$ NPs had a positive effect on wheat growth by increasing photosynthesis, transpiration, and stomatal conductance (Abbas et al. 2020). The effect of $\mathrm{CeO}_{2} \mathrm{NPs}$ may also depend on the plant species. For example, $\mathrm{CeO}_{2}$ NPs did not affect the photosynthetic activity of Raphanus sativa (Corral-Diaz et al. 2014), whereas decreased the Chl and carotenoid contents in Phaseolus vulgaris (Majumdar et al. 2016). Cao et al. (2017) investigated the impact of uncoated and PVP-coated $\mathrm{CeO}_{2}$ NPs on soybean. Their results revealed that uncoated $\mathrm{CeO}_{2} \mathrm{NPs}$ had no significant impact on Chl $a$ or $\mathrm{Chl} b$, whereas PVP-coated $\mathrm{CeO}_{2} \mathrm{NPs}$ increased the Chl $a$ contents of plants (Cao et al. 2017). $\mathrm{CeO}_{2}$ NPs coated with citric acid also increased Chl $a$ and $\mathrm{Chl} b$ contents in Solanum lycopersicum (Barrios

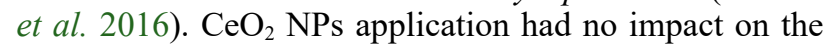
algae Phaeodactylum tricornutum and Chlamydomonas reinhardtii (Sendra et al. 2018).

\section{Silicon nanoparticles (Si NPs)}

Silicon (Si) NPs have the potential to increase plant performance (Rastogi et al. 2019a, Rahimi et al. 2021). A positive impact on photosynthesis and gas exchange has been documented in Si NPs-plant interactions (Mahto et al. 2019). For example, Si NPs increased the total Chl contents and therefore photosynthesis in Zea mays L. (Suriyaprabha et al. 2012). Also, $\mathrm{SiO}_{2}$ NPs showed the same impact on plants as Si NPs (Siddiqui et al. 2014). It has been acknowledged that $\mathrm{SiO}_{2}$ NPs display a positive impact on transpiration, stomatal conductance, PSII, and electron transport chain activity as well as the photosynthetic rate (Siddiqui et al. 2014, Mahto et al. 2019). Elevated contents of Chl $a$ and $\mathrm{Chl} b$ were detected in sugarcane plants treated with $\mathrm{SiO}_{2} \mathrm{NPs}$ (Tayemeh et al. 2020). However, $\mathrm{SiO}_{2}$ NPs caused no significant change in photosynthetic pigments of maize (Zhao et al. 2019). Treatment with $30 \mathrm{mg} \mathrm{L}^{-1}$ of Si quantum dots increased the Chl $a$ and Chl $b$ contents in Lactuca sativa plants (Li et al. 2020). SiC NPs, at concentrations below 150 $\mathrm{mg} \mathrm{L} \mathrm{L}^{-1}$, increased the light absorption, growth, and lipid accumulation in the microalga Scenedesmus sp., however, $250 \mathrm{mg} \mathrm{L}^{-1}$ of SiC NPs decreased the growth and lipid accumulation in this algal species (Ren et al. 2020).

\section{Gold nanoparticles (Au NPs)}

Au NPs are important because of their outstanding properties such as easy synthesis, low toxicity, and visibility by naked eyes due to their optical properties (Torres et al. 2018). Au NPs can have both negative and positive effects on the photosynthetic activities of plants (Mezacasa et al. 2020). Generally, wavelengths beyond $700 \mathrm{~nm}$ are not useful for photosynthesis, however, Au NPs can increase the light absorption not only along with the visible lights (400-700 nm) but in wavelengths above $700 \mathrm{~nm}$ (Eroglu 
Table 2. The effects of $\mathrm{ZnO}$ nanoparticles (NPs) on photosynthesis machinery in different plant/algal species.

\begin{tabular}{|c|c|c|c|c|c|}
\hline Plant/algal species & NPs concentration & NPs size & Growth medium & Effects & Reference \\
\hline Arachis hypogaea & $1,000 \mathrm{mg} \mathrm{kg}^{-1}$ & Not mentioned & Soil & Increasing $\mathrm{Chl}$ content & Kataria et al. (2019) \\
\hline Cucumis sativus & 400 and $800 \mathrm{mg} \mathrm{kg}^{-1}$ & Not mentioned & Soil & Increasing $\mathrm{Chl}$ content & Kataria et al. (2019) \\
\hline $\begin{array}{l}\text { Arabidopsis } \\
\text { thaliana }\end{array}$ & Not mentioned & Not mentioned & Not mentioned & $\begin{array}{l}\text { Improved carotenoids } \\
\text { content, decreased in Chl } \\
\text { and photosynthesis }\end{array}$ & Kataria et al. (2019) \\
\hline $\begin{array}{l}\text { Coriandrum } \\
\text { sativum }\end{array}$ & $100 \mathrm{mg} \mathrm{kg}^{-1}$ & $24 \pm 3 \mathrm{~nm}$ & Soil & $\begin{array}{l}\text { Increasing Chl and carotenoids } \\
\text { content and photosynthesis }\end{array}$ & Pullagurala et al. (2018) \\
\hline Glycine max & Not mentioned & Not mentioned & Not mentioned & Decreasing Chl content & Pullagurala et al. (2018) \\
\hline $\begin{array}{l}\text { Rosmarinus } \\
\text { officinalis }\end{array}$ & $100 \mathrm{mg} \mathrm{kg}^{-1}$ & Not mentioned & Not mentioned & Enhanced carotenoids content & Pullagurala et al. (2018) \\
\hline Zea mays & $800 \mathrm{mg} \mathrm{kg}^{-1}$ & Not mentioned & Soil & $\begin{array}{l}\text { Decreasing net photosynthetic } \\
\text { rate }\end{array}$ & Zhao et al. (2015) \\
\hline $\begin{array}{l}\text { Abelmoschus } \\
\text { esculentus }\end{array}$ & $100 \mathrm{ppm}$ & Not mentioned & Not mentioned & $\begin{array}{l}\text { Increasing } \mathrm{Chl} a, \mathrm{Chl} b \text {, } \\
\text { and total Chl in leaves }\end{array}$ & Salama et al. (2019) \\
\hline $\begin{array}{l}\text { Solanum } \\
\text { lycopersicum }\end{array}$ & $>200 \mathrm{mg} \mathrm{kg}^{-1}$ & $20-30 \mathrm{~nm}$ & Soil & Decreasing Chl content & Iftikhar et al. (2019) \\
\hline $\begin{array}{l}\text { Solanum } \\
\text { lycopersicum }\end{array}$ & $1.2 \mathrm{mM}$ & $1-100 \mathrm{~nm}$ & Sand culture & $\begin{array}{l}\text { Significant increase in Chl } a \\
\text { and Chl } b \text { contents }\end{array}$ & Singh et al. (2016) \\
\hline $\begin{array}{l}\text { Solanum } \\
\text { lycopersicum }\end{array}$ & $50 \mathrm{mg} \mathrm{L}^{-1}$ & 20 and $100 \mathrm{~nm}$ & Soil & \multicolumn{2}{|c|}{$\begin{array}{l}\text { Increasing stomatal conductanceFaizan et al. (2021) } \\
\text { and intracellular } \mathrm{CO}_{2} \text { levels }\end{array}$} \\
\hline $\begin{array}{l}\text { Saccharum } \\
\text { officinarum L. }\end{array}$ & Not mentioned & $<100 \mathrm{~nm}$ & Not mentioned & $\begin{array}{l}\text { Improving Chl index and PSII } \\
\text { function }\end{array}$ & Elsheery et al. (2020) \\
\hline Sesamum indicum & Not mentioned & Not mentioned & $\begin{array}{l}\text { Zink deficient } \\
\text { soil }\end{array}$ & $\begin{array}{l}\text { Increasing photosynthesis } \\
\text { pigments }\end{array}$ & Salama et al. (2019) \\
\hline $\begin{array}{l}\text { Anabaena } \\
\text { flos-aquae }\end{array}$ & $10^{-3} \mathrm{M}$ & Not mentioned & Not mentioned & $\begin{array}{l}\text { Increased in photosynthetic } \\
\text { activity }\end{array}$ & da Rocha et al. (2020) \\
\hline Anabaena sp. & $0.74 \pm 0.01 \mathrm{mg} \mathrm{L}^{-1}$ & $40-50 \mathrm{~nm}$ & $\begin{array}{l}\text { BG11 culture } \\
\text { medium }\end{array}$ & $\begin{array}{l}\text { Making disorder in } \\
\text { photosynthesis and other } \\
\text { metabolic activities }\end{array}$ & Tang et al. (2015) \\
\hline $\begin{array}{l}\text { Chlorella } \\
\text { vulgaris }\end{array}$ & $200 \mathrm{mg} \mathrm{L}^{-1}$ & Not mentioned & Not mentioned & $\begin{array}{l}\text { Decreasing in respiration } \\
\text { efficiency and photosynthesis, } \\
\text { causing shading effect }\end{array}$ & Ren et al. (2020) \\
\hline
\end{tabular}

et al. 2013, Torres et al. 2018). For instance, the application of $\mathrm{Au}$ NPs resulted in an increased $\mathrm{Chl}$ content and photosynthesis in Brassica juncea L. (Mahto et al. 2019). By increasing the concentration of Au NPs, Chl production increased in Vicia faba (Mezacasa et al. 2020). In Vigna radiata plants exposed to $1 \mu \mathrm{g} \mathrm{mg}^{-1}$ of gold nanoparticles (GNPs), aspartate-capped GNPs (GNPA), BSA-capped GNPs (GNPB), and citrate-capped GNPs (GNPC), the Chl content increased in GNPB and GNPC treatments compared to the GNPA and controls (Das et al. 2017).

\section{Copper nanoparticles (Cu NPs)}

Both negative and positive impacts on plants have been established for $\mathrm{Cu}$ NPs. $\mathrm{Cu}$ accumulation (especially $\mathrm{Cu}$ NPs accumulation) in leaves may change the shape of plant stoma and chloroplasts, and also decrease the thylakoids in plants, such as Oryza sativa L., Elodea densa, and Landoltia punctata (Tighe-Neira et al. 2018). CuO NPs inhibited photosynthesis by affecting PSII, causing a decrease in electron transport rate, number of thylakoids, and transpiration in spring barley (Rajput et al. 2018).
Application of 2,000 $\mu \mathrm{g} \mathrm{L}^{-1}$ of $\mathrm{CuO}$ NPs caused cellular toxicity in tomato plants and significantly decreased their growth (Ahmed et al. 2018). CuO NPs (10,000 mg kg-1) decreased the number and size of stoma in spring barley (Tan et al. 2019). Likewise, CuO NPs treatment had a significant negative impact on photosynthetic activities of Quercus robur (Rajput et al. 2018). Treatment with $500 \mathrm{mg} \mathrm{kg}-1$ of $\mathrm{CuO}$ NPs decreased the total Chl contents in wheat (Tan et al. 2019). However, CuO NPs may have a positive effect on photosynthesis. For example, $\mathrm{Cu}$ NPs were demonstrated to increase the transpiration, stomatal conductance, and rate of electron transport chain in Capsicum annuum (Rawat et al. 2019). In addition, $\mathrm{CuO}$ NPs increased the Chl contents and photosynthetic activities in mung beans (Kataria et al. 2019). Treatment with $\mathrm{CuO}$ NPs inhibited photosynthesis and decreased the PSII operational quantum yield in the aquatic flowering plant Lemna gibba (gibbous duckweed) (Sharma and Uttam 2017). Total carotenoid content decreased significantly in duckweed upon exposure to a low concentration of $\mathrm{CuO}$ NPs (Tan et al. 2019). In the single-celled green alga Chlamydomonas reinhardtii, the $\mathrm{Chl} a$ and $\mathrm{Chl} b$ contents 
decreased by exposure to $\mathrm{CuO}$ NPs (Middepogu et al. 2018). Cu NPs did not significantly affect the maximal quantum yield of PSII $\left(\mathrm{F}_{\mathrm{v}} / \mathrm{F}_{\mathrm{m}}\right)$ in barley (Hordeum vulgare L. landrace Arabi Aswad), however, enhanced flavonol content with concomitant improvement in ascorbate peroxidase activity was found to be insufficient to enforce a light control over the $\mathrm{H}_{2} \mathrm{O}_{2}$ content under $\mathrm{Cu}$ NPs stress conditions (Shaw et al. 2014).

\section{Other metal nanoparticles}

Other metal NPs have not been widely investigated in terms of their interactions with plants. $\mathrm{Mn}_{3} \mathrm{O}_{4}$ NPs can increase the photosynthetic potential of mesophyll protoplasts (Wang et al. 2020). Mn NPs were shown to positively affect photosynthesis in Vigna radiata by improving the photophosphorylation activity in the electron transport chain (Kataria et al. 2019). Similarly, $\mathrm{Al}_{2} \mathrm{O}_{3} \mathrm{NPs}(20 \mathrm{~nm})$ increased the electron chain efficiency, PSII performance, and photosynthesis in the aquatic plant Lemna minor (Ahmed et al. 2018). Chitosan NPs improved the net photosynthetic rate and $\mathrm{CO}_{2}$ concentration of coffee (Kataria et al. 2019).

$\mathrm{Ni}(\mathrm{OH})_{2}$ had no significant impact on soybeans and Prosopis sp., whereas NiO NPs decreased photosynthesis (Mishra et al. 2014). Ni ions displace Mg ions and alter the structure of Chl molecules, which was suggested to be the mechanism underlying the decreased photosynthetic efficiency in Lycium barbarum (Pinto et al. 2019). Application of $120 \mathrm{mg} \mathrm{kg}^{-1}$ of NiO NPs decreased the Chl contents in barley (Pinto et al. 2019). In the microalga Pseudokirchneriella subcapitata, NiO NPs decreased the electron transport rate and photosynthetic efficiency (Sousa et al. 2018).

Platinum $(\mathrm{Pt}) \mathrm{NPs}$ decreased the Chl content and growth of the single-celled green algal species Chlamydomonas reinhardtii (Röhder et al. 2014) and Pseudokirchneriella subcapitata (Książyk et al. 2015). Nonetheless, our knowledge of the effects of Pt NPs on photosynthesis is quite limited (Tighe-Neira et al. 2018).

Selenium (Se) NPs increased the total Chl contents in Punica grantum cv. Malase Saveh (Zahedi et al. 2019). Moreover, Se NPs were proven to increase the leaf area in both cluster bean (300-400 $\mathrm{mg} \mathrm{L}^{-1}$ ) and orange trees (50 $\mathrm{mg} \mathrm{L}^{-1}$ ) (Zahedi et al. 2019). However, it has been acknowledged that Se (IV) reveals dual effects on pigments content, gas-exchange parameters, net photosynthetic rate $\left(P_{\mathrm{N}}\right)$, and PSII photochemical efficiency $\left(\mathrm{F}_{\mathrm{v}} / \mathrm{F}_{\mathrm{m}}\right)$ of Brassica napus cultivars in a dose-dependent manner (Ulhassan et al. 2018, 2019a,b).

The protein-loaded mPEG-PLGA NPs increased the photosynthetic parameters such as $\mathrm{Chl}$ content in wheat (Gao et al. 2018). CdO NPs decreased $\mathrm{CO}_{2}$ absorption and also inhibited energy transportation from PSII to Calvin cycle in barley (Večeřová et al. 2016). CdS NPs reduced the photosynthetic activities in Euglena gracilis by causing cell death (da Rocha et al. 2020). Photosynthesis, transpiration rate, and also stomatal conductance decreased in soybean and maize plants subjected to $\mathrm{La}_{2} \mathrm{O}_{3}$
NPs, however, these adverse effects were more severe in maize $\left(\mathrm{C}_{4}\right.$ plant $)$, compared to soybean $\left(\mathrm{C}_{3}\right.$ plant) (Liu et al. 2020).

\section{Magnetic nanoparticles}

Nanoparticles with magnetic properties can be used to stimulate the photosynthetic activities of plants (Baker et al. 2019, Tombuloglu et al. 2019). Fe, Ni, Co, and their chemical combinations are some examples of magnetic NPs (Tombuloglu et al. 2019).

Iron is essential for plants and its deficiency can reduce the $\mathrm{Chl}$ content, leading to reduction or inhibition of photosynthesis (Mohammadi et al. 2018, 2020; Mahto et al. 2019). Fe NPs can also increase the photosynthetic potential of mesophyll (Wang et al. 2020). Treatment with Fe NPs increased the essential oil content of Mentha piperita (Askary et al. 2017). Enhanced Chl concentration was observed in $A$. thaliana plants treated with Fe NPs (Marusenko et al. 2013). Application of 30-60 ppm of Fe NPs increased the Chl surface in soybean (Thapa et al. 2019). Exposure to Fe NPs increased the photosynthetic rate, PSII activity, and shoot growth in spinach (Spinacia oleracea) (Jeyasubramanian et al. 2016, Wang et al. 2020). Fe NPs significantly increased the Chl $a$ and Chl $b$ contents in both Vigna radiata and Hordeum vulgare (Pagano et al. 2018, Tombuloglu et al. 2019). Fe NPs were also shown to promote the growth of Capsicum annuum plants (Tombuloglu et al. 2019). Fe NPs application enhanced the $\mathrm{Chl}$ contents in tree species, such as Citrus maxima (Li et al. 2018, Baker et al. 2019) and Quercus macdougallii (Tombuloglu et al. 2019). $\mathrm{Fe}_{3} \mathrm{O}_{4}$ NPs application also increased Chl $b$ in Zea mays (Zhao et al. 2019). Application of 500 and $1,000 \mathrm{mg} \mathrm{L}^{-1}$ of $\mathrm{Fe}$ NPs increased the photosynthetic rate in soybean (Maswada et al. 2018). $\mathrm{Fe}_{2} \mathrm{O}_{3}$ NPs coated with citric acid also increased the photosynthetic rate in soybean (Kataria et al. 2019). As an example of negative $\mathrm{Fe}$ NPs-plant interactions, treatment with $72 \mu \mathrm{M}$ of $\mathrm{Fe}_{2} \mathrm{O}_{3}$ NPs decreased the Chl $a$ and $\mathrm{Chl} b$ contents in $A$. thaliana (Pagano et al. 2018). Exposure to superparamagnetic FeO NPs (SPION) increased the Chl content in subapical leaves of soybean (Ghafariyan et al. 2013, Kataria et al. 2019). However, these NPs showed a shading effect in the algal species $C$. reinhartii, leading to a significant reduction in photosynthesis (Hurtado-Gallego et al. 2020). Application of SPIONs also inhibited the Chl production and photosynthesis in the gibbous duckweed Lemna gibba (Hurtado-Gallego et al. 2020).

Cobalt (Co) NPs are another example of magnetic NPs that were demonstrated to have a positive effect on $\mathrm{Chl} a$, Chl $b$, and total Chl of mung bean (Vigna radiata) (Ha et al. 2020).

\section{Effects of nanoparticles on stressed plants}

Environmental stresses can decrease the photosynthesis indices in plants, however, studies have shown that NPs can prevent or ameliorate the adverse effects of stresses 
on plants (Baiazidi-Aghdam et al. 2016, Sheikhalipour et al. 2021). For example, $1-1,000 \mathrm{mg} \mathrm{L}^{-1}$ of fullerenols NPs decreased the negative effects of water stress in canola (Brassica napus) (Verma et al. 2019). Exposure to 200-1,000 $\mathrm{mg} \mathrm{L}^{-1}$ of $\mathrm{CeO}_{2}$ NPs stimulated the photosynthesis machinery and the total Chl contents in salt-stressed (100 mM) canola plants (Rossi et al. 2016). In a different study, $\mathrm{CeO}_{2}$ NPs application improved the salt stress tolerance of canola by promoting the formation of apoplastic barriers in roots (Rossi et al. 2017). Also, the application of $\mathrm{SiO}_{2} \mathrm{NPs}$ increased the Chl content and biomass of Spinacia oleracea, as well as mesophyll conductance in Cucurbita pepo under salt-stress conditions (Kataria et al. 2019, Zhao et al. 2020). Si NPs also increased the photosynthetic rate in salt-stressed cucumber and rice (Elsheery et al. 2020). The application of $100 \mathrm{mg} \mathrm{L}^{-1}$ of $\mathrm{Fe}_{2} \mathrm{O}_{3} \mathrm{NPs}$ increased the photosynthetic rate in salt-stressed sorghum (Maswada et al. 2018).

Contents of photosynthetic pigments increased in lupin plants under salt stress upon exposure to ZnO NPs (Kataria et al. 2019). A combined application of microand nano-carbon increased the growth of chickpea plants in Cr-stressed soil (Kumar et al. 2020). The PSII activity, Chl content, and plant growth decreased in salt-stressed maize, whereas chitosan NPs mitigated these destructive effects (Yasmeen et al. 2018). Although salt stress had negative effects on the photosynthesis of Dracocephalum moldavica, $\mathrm{TiO}_{2}$ NPs treatment reduced these negative effects (Gohari et al. 2020). Water deficit and salt-stressed cucumber plants treated with $200 \mathrm{mg} \mathrm{kg}^{-1}$ of Si NPs had significantly higher $\mathrm{Chl}$ contents compared to untreated plants; in fact, Si application increased the uptake of $\mathrm{Mg}$, i.e., a key element in Chl structure (Alsaeedi et al. 2019).

Drought stress decreased the Chl index and stomatal conductance in sorghum, whereas foliar Ce NPs application improved these photosynthetic parameters (Djanaguiraman et al. 2018). In addition, abiotic stresses (excess light, heat, and dark chilling) decreased photosynthesis in A. thaliana, while treatment with $\mathrm{CeO}_{2}$ NPs increased photosynthesis (Wu et al. 2017). Exposure to 3,200 mg L-1 of $\mathrm{SiO}_{2} \mathrm{NPs}$ increased the growth of drought-stressed cotton plants (Zhao et al. 2020). UV-B-stressed wheat seedlings exhibited disrupted photosynthesis, whereas Si NPs application promoted their photosynthesis via altering the ROS equilibrium (Tripathi et al. 2017c). In cold-stressed chickpea, $\mathrm{TiO}_{2} \mathrm{NPs}$ treatment stabilized the cell metabolic processes such as photosynthesis (Hasanpour et al. 2015). $\mathrm{TiO}_{2}$ NPs application led to an enhanced adaptation of chickpea plants to cold stress (Amini et al. 2017). However, NPs-treated plants can adapt or cope with environmental perturbations and unfavorable conditions, such as drought, salinity, trace elements, chilling, and heat stress (Ali et al. 2021) through different enzymatic and nonenzymatic reactions (Ahmadi et al. 2020, Ghorbanpour et al. 2020). For example, MWCNTs have been documented to be involved in upregulating stress-specific gene expression such as HSP90 (Khodakovskaya et al. 2011). The possible mechanisms of augmented photosynthesis in stressed plants through the application of NPs (in optimum dose) are illustrated in Fig. 2.

\section{Combined application of nanoparticles and soil amendments}

The combined application of biochar and Ag NPs led to reduced negative impacts on rice plants, in comparison to plants only treated with Ag NPs; in fact, biochar amendment ameliorated the toxic effects of Ag NPs on photosynthetic and physiological parameters in these plants (Abbas et al. 2019). Treatment with a low concentration of ZnO NPs with amended citric acid increased the growth of cowpea (Vigna unguiculata L.) (Cyriac et al. 2020). The combination of diuron and CNTs also increased the growth of the green microalga Chlorella vulgaris (Schwab et al. 2013). Nonetheless, these sorts of combined applications may not necessarily lead to desirable outcomes. For example, treatment with $\mathrm{CeO}_{2} \mathrm{NPs}$ and alginate decreased the $\mathrm{Chl} a$ fluorescence in maize in all applied concentrations (Zhao et al. 2014). Moreover, the EC50 of ZnO NPs, against the filamentous cyanobacterium Anabaena, increased in the presence of humic acid (Tang et al. 2015).

\section{Possible mechanisms underlying improvement of photosynthesis by NPs}

Multiple mechanisms are involved in the augmentation of plant photosynthesis upon exposure to NPs, however, the exact mechanisms are not sufficiently clear or deeply understood (Kataria et al. 2019). The schematic illustration of NPs-induced changes in plant photosynthesis is presented in Fig. 3. As shown, NPs can expand the absorption wavelength range. The photosynthesis process is mainly dependent on the availability of the visible spectrum. However, specific NPs convert near-infrared (IR) and ultraviolet (UV) wavelengths to visible light, resulting in improved electron transport (Liu et al. 2019). Lightharvesting NPs may capture and transfer more electrons for tuning photosynthetic efficiency, specifically under light-insufficient conditions (Wu and Lin 2021). Moreover, NPs may enhance the photosynthetic performance mainly by light-dependent (Hill reaction) and light-independent (Calvin cycle) reactions (PSI and PSII activities), leading to greater oxygen evolution and photophosphorylation (Pradhan et al.2015, Swift et al.2019). The NPs-augmented photosynthetic efficiency may arise from the upregulation of key photosynthetic enzymes, such as Rubisco, Rubisco activase, fructose-1,6-bisphosphate phosphatase (FBPase), ribulose-5-phosphate kinase (RBPase), and NADP-glyceraldehyde-3-phosphate dehydrogenase (GPDHase), and phosphoenolpyruvate carboxylase (PEPC) (Gao et al. 2006, Pradhan et al. 2015, Liu et al. 2019). It has been acknowledged that certain NPs play a vital role in stress defense mechanisms by scavenging stress-induced ROS in a dose-dependent manner (Corral-Diaz et al. 2014, Wu et al. 2018). Recently, nanobionics has been introduced as a powerful technique to increase the function of photosynthetic organelles of plants by augmenting the lightharvesting ability and enhancing the ROS-scavenging capacity under stress conditions (Giraldo et al. 2014, Ghorbanpour and Fahimirad 2017). 

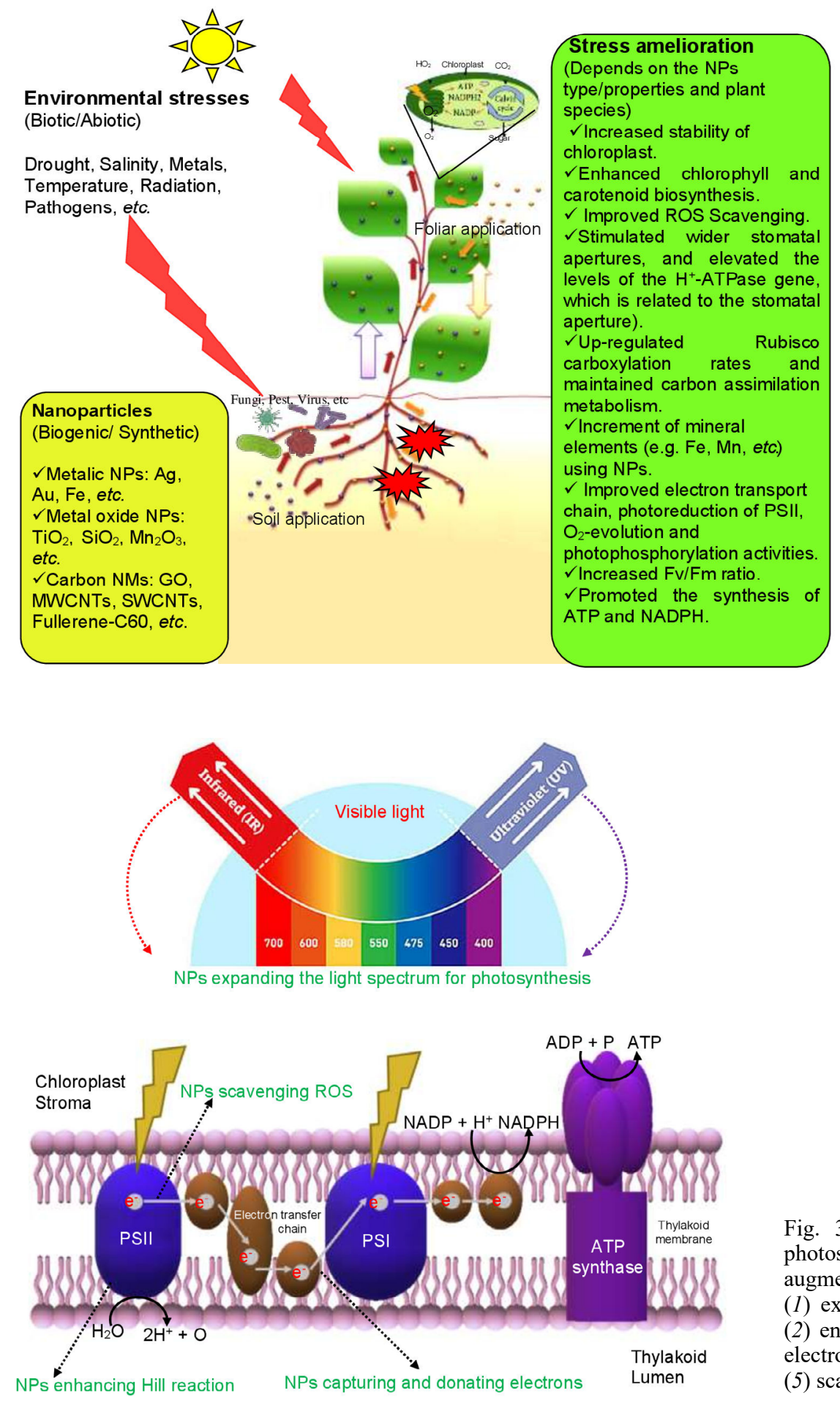

Fig. 2. Possible regulating factors of augmented photosynthesis in stressed plants by application of nanoparticles (NPs) in optimum dose. Exposure to NPs increased the mitigating ability of photosynthetic machinery under different environmental stresses.

\section{Conclusions and future perspectives}

Although nanoparticles (NPs) are widely used in different industries, their potential applications in certain fields such as agriculture and plant science are underestimated. Due to their nanoscale and unique physicochemical properties, NPs can easily and effectively affect diverse biochemical pathways in plant cells. Nanoparticles can
Fig. 3. Role of nanoparticles (NPs) in plant photosynthesis. This model depicts that NPs may augment the photosynthetic efficiency through (1) expanding the absorption wavelength range, (2) enhancing Hill reaction, (3) harvesting more electrons, (4) accelerating electron transfer, (5) scavenging ROS. 
pathways and biosynthesis of photosynthetic pigments. This comprehensive review of the literature showed that NPs might have both positive and negative effects on photosynthesis. Positive effects can be attributed to increases in the biosynthesis of $\mathrm{Chl}$, the activity of Rubisco enzyme, the performance of PSII, enhanced lightharvesting complex (LHC), and $\mathrm{CO}_{2}$ harvesting, as well as broadening the chloroplast photoabsorption spectrum, whereas the negative effects can occur due to damages to chloroplast structures, decreases in the biosynthesis of $\mathrm{Chl}$ and electron transport rate by changing several genes and enzymes such as carbonic anhydrase and PEPC. These possible impacts provide insights into the potential applications of NPs to boost photosynthesis in crops, or strategies/considerations to reduce the negative environmental footprint of NPs. Most studies have focused on the overall outcome of NPs on photosynthesis (e.g., contents of photosynthetic pigments, photosynthetic rate, PSII activity, etc.), while little is known about the details of the NPs-chloroplast interactions (e.g., NPs entry to the chloroplast, main target molecules, and enzymes affected, etc.), which need to be investigated. Furthermore, nearly all studies have been conducted under controlled environmental conditions (glasshouses and laboratories), while it is crucial to explore the impacts of NPs on photosynthetic parameters of plants under field (natural) conditions. Exposure to NPs increases the tolerance level of plants against various biotic and abiotic environmental stresses, but the mechanisms underlying this regulation are not fully understood yet. Further investigations are required to better understand the regulation of gene expression in plants exposed to various metal/metaloxide and carbon-based NPs under stressful conditions. Mechanisms, by which chloroplasts may be engineered with NPs to extend their functions, called nanobionics, await further investigation.

\section{References}

Abbas Q., Liu G.J., Yousaf B. et al.: Effects of biochar on uptake, acquisition and translocation of silver nanoparticles in rice (Oryza sativa L.) in relation to growth, photosynthetic traits and nutrients displacement. - Environ. Pollut. 250: 728-736, 2019.

Abbas Q., Liu G.J. Yousaf B. et al.: Biochar-assisted transformation of engineered-cerium oxide nanoparticles: Effect on wheat growth, photosynthetic traits and cerium accumulation. - Ecotox. Environ. Safe. 187: 109845, 2020.

Ahmad B., Shabbir A., Jaleel H. et al.: Efficacy of titanium dioxide nanoparticles in modulating photosynthesis, peltate glandular trichomes and essential oil production and quality in Mentha piperita L. - Curr. Plant Biol. 13: 6-15, 2018.

Ahmadi S.Z, Ghorbanpour M., Aghaee A., Hadian J.: Deciphering morpho-physiological and phytochemical attributes of Tanacetum parthenium L. plants exposed to C60 fullerene and salicylic acid. - Chemosphere 259: 127406, 2020.

Ahmed B., Khan M.S., Musarrat J.: Toxicity assessment of metal oxide nano-pollutants on tomato (Solanum lycopersicon): A study on growth dynamics and plant cell death. - Environ. Pollut. 240: 802-816, 2018.

Ali A., Mehmood A., Khan N.: Uptake, translocation, and consequences of nanomaterials on plant growth and stress adaptation. - J. Nanomater. 2021: 6677616, 2021.

Alsaeedi A., El-Ramady H., Alshaal T. et al.: Silica nanoparticles boost growth and productivity of cucumber under water deficit and salinity stresses by balancing nutrients uptake. Plant Physiol. Bioch. 139: 1-10, 2019.

Amini S., Maali-Amiri R., Mohammadi R., Kazemi-Shahandashti S.-S.: cDNA-AFLP analysis of transcripts induced in chickpea plants by $\mathrm{TiO}_{2}$ nanoparticles during cold stress. Plant Physiol. Bioch. 111: 39-49, 2017.

Amooaghaie R., Tabatabaei F., Ahadi A.: Alterations in HO-l expression, heme oxygenase activity and endogenous NO homeostasis modulate antioxidant responses of Brassica nigra against nano silver toxicity. - J. Plant Physiol. 228: 75-84, 2018.

Askary M., Talebi S.M., Amini F., Bangan A.D.B.: Effect of $\mathrm{NaCl}$ and iron oxide nanoparticles on Mentha piperita essential oil composition. - Environ. Exp. Biol. 14: 27-32, 2017.

Baiazidi-Aghdam M.T., Mohammadi H., Ghorbanpour M.: Effects of nanoparticulate anatase titanium dioxide on physiological and biochemical performance of Linum usitatissimum (Linaceae) under well watered and drought stress conditions. - Braz. J. Bot. 39: 139-146, 2016.

Baker S., Satish S., Prasad N., Chouhan R.S.: Nano-agromaterials: Influence on plant growth and crop protection. - In: Thomas S., Grohens Y., Pottathara Y.B. (ed.): Industrial Applications of Nanomaterials. Pp. 341-363. Elsevier Academic Press, Amsterdam 2019.

Barrios A.C., Rico C.M., Trujillo-Reyes J. et al.: Effects of uncoated and citric acid coated cerium oxide nanoparticles, bulk cerium oxide, cerium acetate, and citric acid on tomato plants. - Sci. Total Environ. 563-564: 956-964, 2016.

Cao Z., Stowers C., Rossi L. et al.: Physiological effects of cerium oxide nanoparticles on the photosynthesis and water use efficiency of soybean (Glycine max (L.) Merr.). - Environ. Sci.-Nano 4: 1086-1094, 2017.

Chandra S., Pradhan S., Mitra S. et al.: High throughput electron transfer from carbon dots to chloroplast: a rationale of enhanced photosynthesis. - Nanoscale 6: 3647-3655, 2014.

Chen J., Liu B., Yang Z. et al.: Phenotypic, transcriptional, physiological and metabolic responses to carbon nanodot exposure in Arabidopsis thaliana (L.). - Environ. Sci.-Nano 5: 2672-2685, 2018.

Chen L., Wang C., Yang S. et al.: Chemical reduction of graphene enhances in vivo translocation and photosynthetic inhibition in pea plants. - Environ. Sci.-Nano 6: 1077-1088, 2019.

Chen L., Zhou L., Liu Y. et al.: Toxicological effects of nanometer titanium dioxide (nano- $\mathrm{TiO}_{2}$ ) on Chlamydomonas reinhardtii.Ecotox. Environ. Safe. 84: 155-162, 2012.

Choi S.A., Jeong Y., Lee J. et al.: Biocompatible liquid-type carbon nanodots (C-paints) as light delivery materials for cell growth and astaxanthin induction of Haematococcus pluvialis. - Mater. Sci. Eng. C 109: 110500, 2020.

Conway J.R., Beaulieu A.L., Beaulieu N.L. et al.: Environmental stresses increase photosynthetic disruption by metal oxide nanomaterials in a soil-grown plant. - ACS Nano 9: 11737 11749, 2015.

Corral-Diaz B., Peralta-Videa J.R, Alvarez-Parrilla E. et al. Cerium oxide nanoparticles alter the antioxidant capacity but do not impact tuber ionome in Raphanus sativus (L). - Plant Physiol Bioch. 84: 277-285, 2014.

Cox A., Venkatachalam P., Sahi S., Sharma N.: Silver and titanium dioxide nanoparticle toxicity in plants: a review of current research. - Plant Physiol. Bioch. 107: 147-163, 2016.

Cyriac J., Melethil K., Thomas B. et al.: Synthesis of biogenic $\mathrm{ZnO}$ nanoparticles and its impact on seed germination and root growth of Oryza sativa L. and Vigna unguiculata L. - 
Mater. Today: Proc. 25: 224-229, 2020.

da Rocha A., Menguy N., Yéprémian C. et al.: Ecotoxicological studies of $\mathrm{ZnO}$ and $\mathrm{CdS}$ nanoparticles on Chlorella vulgaris photosynthetic microorganism in Seine river water. Nanomaterials 10: 227, 2020.

Dai Y., Chen F., Yue L. et al.: Uptake, transport, and transformation of $\mathrm{CeO}_{2}$ nanoparticles by strawberry and their impact on the rhizosphere bacterial community. - ACS Sustain. Chem. Eng. 8: 4792-4800, 2020.

Das S., Debnath N., Pradhan S., Goswami A.: Enhancement of photon absorption in the light-harvesting complex of isolated chloroplast in the presence of plasmonic gold nanosol a nanobionic approach towards photosynthesis and plant primary growth augmentation. - Gold Bull. 50: 247-257, 2017.

Dauda S., Chia M.A., Bako S.P.: Toxicity of titanium dioxide nanoparticles to Chlorella vulgaris Beyerinck (Beijerinck) 1890 (Trebouxiophyceae, Chlorophyta) under changing nitrogen conditions. - Aquat. Toxicol. 187: 108-114, 2017.

Djanaguiraman M., Nair R.,. Giraldo J.P., Prasad P.V.V.: Cerium oxide nanoparticles decrease drought-induced oxidative damage in sorghum leading to higher photosynthesis and grain yield. - ACS Omega 3: 14406-14416, 2018.

El Naschie M.S.: Nanotechnology for the developing world. Chaos Solitons Fractals 30: 769-773, 2006.

Elsheery N.I., Sunoj V.S.J., Wen Y. et al.: Foliar application of nanoparticles mitigates the chilling effect on photosynthesis and photoprotection in sugarcane. - Plant Physiol. Bioch. 149: 50-60, 2020.

Eroglu E., Eggers P.K., Winslade M. et al.: Enhanced accumulation of microalgal pigments using metal nanoparticle solutions as light filtering devices. - Green Chem. 15: 3155-3159, 2013.

Etxeberria E., Gonzalez P., Baroja-Fernandez E., Romero J.P.: Fluid phase endocytic uptake of artificial nano-spheres and fluorescent quantum dots by sycamore cultured cells: evidence for the distribution of solutes to different intracellular compartments. - Plant Signal. Behav. 1: 196-200, 2006.

Fahimirad S., Ajalloueian F., Ghorbanpour M.: Synthesis and therapeutic potential of silver nanomaterials derived from plant extracts. - Ecotox. Environ. Safe. 168: 260-278, 2019.

Faizan M., Faraz A., Mir A.R., Hayat S.: Role of zinc oxide nanoparticles in countering negative effects generated by cadmium in Lycopersicon esculentum. - J. Plant Growth Regul. 40: 101-115, 2021.

Falco W.F., Scherer M.D., Oliveira S.L. et al.: Phytotoxicity of silver nanoparticles on Vicia faba: Evaluation of particle size effects on photosynthetic performance and leaf gas exchange. - Sci. Total Environ. 701: 134816, 2020.

Fan X., Xu J., Lavoie M. et al.: Multiwall carbon nanotubes modulate paraquat toxicity in Arabidopsis thaliana. Environ. Pollut. 233: 633-641, 2018.

Faraji J., Sepehri A.: Exogenous nitric oxide improves the protective effects of $\mathrm{TiO}_{2}$ nanoparticles on growth, antioxidant system, and photosynthetic performance of wheat seedlings under drought stress. - J. Soil Sci. Plant Nutr. 20: 703-714, 2020.

Gade A., Ingle A., Whiteley C., Rai M.: Mycogenic metal nanoparticles: progress and applications. - Biotechnol. Lett. 32: 593-600, 2010.

Gao F.Q., Hong F.S., Liu C. et al.: Mechanism of nano-anatase $\mathrm{TiO}_{2}$ on promoting photosynthetic carbon reaction of spinach: inducing complex of Rubisco-Rubisco activase. - Biol. Trace Elem. Res. 111: 239-253, 2006.

Gao F.Q., Liu C., Qu C.X. et al.: Was improvement of spinach growth by nano- $\mathrm{TiO}_{2}$ treatment related to the changes of Rubisco activase? - Biometals 21: 211-217, 2008.
Gao H., Qin Y., Guo R. et al.: Enhanced plant growth promoting role of mPEG-PLGA-based nanoparticles as an activator protein PeaT1 carrier in wheat (Triticum aestivum L.). J. Chem. Technol. Biotechnol. 93: 3143-3151, 2018.

Ghafariyan M.H., Malakouti M.J., Dadpour M.R. et al.: Effects of magnetite nanoparticles on soybean chlorophyll. - Environ. Sci. Technol. 47: 10645-10652, 2013.

Ghazaei F., Shariati M.: Effects of titanium nanoparticles on the photosynthesis, respiration, and physiological parameters in Dunaliella salina and Dunaliella tertiolecta. - Protoplasma 257: 75-88, 2020.

Ghorbanpour M., Fahimirad S.: Plant nanobionics: a novel approach to overcome the environmental challenges. - In: Ghorbanpour M., Varma A. (ed.): Medicinal Plants and Environmental Challenges. Pp. 247-257. Springer, Cham 2017.

Ghorbanpour M., Hadian J.: Multi-walled carbon nanotubes stimulate callus induction, secondary metabolites biosynthesis and antioxidant capacity in medicinal plant Satureja khuzestanica grown in vitro. - Carbon 94: 749-759, 2015.

Ghorbanpour M., Hatami M.: Spray treatment with silver nanoparticles plus thidiazuron increases anti-oxidant enzyme activities and reduces petal and leaf abscission in four cultivars of geranium (Pelargonium zonale) during storage in the dark. - J. Hortic. Sci. Biotech. 89: 712-718, 2014.

Ghorbanpour M., Khaltabadi Farahani A.H., Hadian J.: Potential toxicity of nano-graphene oxide on callus cell of Plantago major L. under polyethylene glycol-induced dehydration. Ecotox. Environ. Safe. 148: 910-922, 2018.

Ghorbanpour M., Mohammadi H., Kariman K.: Nanosiliconbased recovery of barley (Hordeum vulgare) plants subjected to drought stress. - Environ. Sci.-Nano 7: 443-461, 2020.

Giraldo J.P., Landry M.P., Faltermeier S.M. et al.: Plant nanobionics approach to augment photosynthesis and biochemical sensing. - Nat. Mater. 13: 400-408, 2014.

Gogotsi Y. (ed.): Nanomaterials Handbook. $1^{\text {st }}$ Edition. Pp. 800. CRC Press, Boca Raton 2006.

Gohari G., Mohammadi A., Akbari A. et al.: Titanium dioxide nanoparticles $\left(\mathrm{TiO}_{2} \mathrm{NPs}\right)$ promote growth and ameliorate salinity stress effects on essential oil profile and biochemical attributes of Dracocephalum moldavica. - Sci. Rep.-UK 10: 912, 2020.

Gong Y., Zhao J.: Small carbon quantum dots, large photosynthesis enhancement. - J. Agr. Food Chem. 66: 9159-9161, 2018.

Ha N.T.M., Do C.M., Hoang T.T. et al.: The effect of cobalt and silver nanoparticles on overcoming leaf abscission and enhanced growth of rose (Rosa hybrida L. 'Baby Love') plantlets cultured in vitro. - Plant Cell Tiss. Org. Cult. 141: 393-405, 2020.

Hajian M.H., Ghorbanpour M., Abtahi F., Hadian J.: Differential effects of biogenic and chemically synthesized silver-nanoparticles application on physiological traits, antioxidative status and californidine content in California poppy (Eschscholzia californica Cham). - Environ. Pollut. 292: 118300, 2022.

Hasanpour H., Maali-Amir R., Zeinali H.: Effect of $\mathrm{TiO}_{2}$ nanoparticles on metabolic limitations to photosynthesis under cold in chickpea. - Russ. J. Plant Physiol. 62: 779-787, 2015.

Hatami M., Ghorbanpour M.: Effect of nanosilver on physiological performance of Pelargonium plants exposed to dark storage. - J. Hortic. Res. 21: 15-20, 2013.

Hatami M., Ghorbanpour M.: Defense enzymes activity and biochemical variations of Pelargonium zonale in response to nanosilver particles and dark storage. - Turk. J. Biol. 38: 
130-139, 2014.

Hatami M., Ghorbanpour M., Salehiarjomand H.: Nano-anatase $\mathrm{TiO}_{2}$ modulates the germination behavior and seedling vigority of the five commercially important medicinal and aromatic plants. - J. Biol. Environ. Sci. 8: 53-59, 2014.

Hatami M., Hadian J., Ghorbanpour M.: Mechanisms underlying toxicity and stimulatory role of single-walled carbon nanotubes in Hyoscyamus niger during drought stress simulated by polyethylene glycol. - J. Hazard. Mater. 324: 306-320, 2017.

Hatami M., Hosseini S.M., Ghorbanpour M., Kariman K.: Physiological and antioxidative responses to GO/PANI nanocomposite in intact and demucilaged seeds and young seedlings of Salvia mirzayanii. - Chemosphere 233: 920-935, 2019b.

Hatami M., Kariman K., Ghorbanpour M.: Engineered nanomaterial-mediated changes in the metabolism of terrestrial plants. - Sci. Total Environ. 571: 275-291, 2016.

Hatami M., Naghdi Badi H., Ghorbanpour M.: Nano-elicitation of secondary pharmaceutical metabolites in plant cells: a review. - J. Med. Plants 18: 6-36, 2019a.

Hong F.S., Yang P., Gao F.Q. et al.: Effect of nano-anatase $\mathrm{TiO}_{2}$ on spectral characterization of photosystem particles from spinach. - Chem. Res. Chin. Univ. 21: 196-200, 2005.

Hu C., Liu L., Li X. et al.: Effect of graphene oxide on copper stress in Lemna minor L.: evaluating growth, biochemical responses, and nutrient uptake. - J. Hazard. Mater. 341: 168$176,2018$.

Hu J., Wu X., Wu F. et al:: Potential application of titanium dioxide nanoparticles to improve the nutritional quality of coriander (Coriandrum sativum L.). - J. Hazard. Mater. 389: 121837, 2020.

Huang J., Cheng J., Yi J.: Impact of silver nanoparticles on marine diatom Skeletonema costatum. - J. Appl. Toxicol. 36: 1343-1354, 2016.

Hurtado-Gallego J., Pulido-Reyes G., González-Pleiter M. et al.: Toxicity of superparamagnetic iron oxide nanoparticles to the microalga Chlamydomonas reinhardtii. - Chemosphere 238: $124562,2020$.

Hussain S., Iqbal N., Brestic M. et al.: Changes in morphology, chlorophyll fluorescence performance and Rubisco activity of soybean in response to foliar application of ionic titanium under normal light and shade environment. - Sci. Total Environ. 658: 626-637, 2019.

Hussain S., Shafiq I., Chattha M.S. et al.: Effect of Ti treatments on growth, photosynthesis, phosphorus uptake and yield of soybean (Glycine max L.) in maize-soybean relay strip intercropping. - Environ. Exp. Bot. 187: 104476, 2021.

Iftikhar A., Ali S., Yasmeen T. et al.: Effect of gibberellic acid on growth, photosynthesis and antioxidant defense system of wheat under zinc oxide nanoparticle stress. - Environ. Pollut. 254: 113109, 2019.

Jeyasubramanian K., Thoppey U.U.G., Hikku G.S. et al.: Enhancement in growth rate and productivity of spinach grown in hydroponics with iron oxide nanoparticles. - RSC Adv. 6: 15451-15459, 2016.

Jia W., Zhai S., Ma C. et al.: The role of different fractions of humic acid in the physiological response of amaranth treated with magnetic carbon nanotubes. - Ecotox. Environ. Safe. 169: 848-855, 2019.

Johal M.S., Johnson L.E.: Understanding Nanomaterials. Pp. 528. CRC Press, Boca Raton 2018.

Joshi A., Sharma L., Kaur S. et al.: Plant nanobionic effect of multi-walled carbon nanotubes on growth, anatomy, yield and grain composition of rice. - BioNanoScience 10: 430-445, 2020 .
Kataria S., Jain M., Rastogi A. et al.: Role of nanoparticles on photosynthesis: avenues and applications. - In: Tripathi D.K., Ahmad P., Sharma S., Dubey N.K. (ed.): Nanomaterials in Plants, Algae and Microorganisms. Pp. 103-127. Academic Press, London 2019.

Khodakovskaya M.V., de Silva K., Nedosekin D.A. et al.: Complex genetic, photothermal, and photoacoustic analysis of nanoparticle-plant interactions. - P. Natl. Acad. Sci. USA 108: 1028-1033, 2011.

Książyk M., Asztemborska M., Stęborowski R., BystrzejewskaPiotrowska G.: Toxic effect of silver and platinum nanoparticles toward the freshwater microalga Pseudokirchneriella subcapitata. - B. Environ. Contam. Tox. 94: 554-558, 2015.

Kumar A., Gahoi P., Verma N.: Simultaneous scavenging of $\mathrm{Cr}(\mathrm{VI})$ from soil and facilitation of nutrient uptake in plant using a mixture of carbon microfibers and nanofibers. Chemosphere 239: 124760, 2020.

Li J., Hu J., Xiao L. et al.: Interaction mechanisms between $\alpha-\mathrm{Fe}_{2} \mathrm{O}_{3}, \gamma-\mathrm{Fe}_{2} \mathrm{O}_{3}$ and $\mathrm{Fe}_{3} \mathrm{O}_{4}$ nanoparticles and Citrus maxima seedlings. - Sci. Total Environ. 625: 677-685, 2018.

Li X., Schirmer K., Bernard L. et al.: Silver nanoparticle toxicity and association with the alga Euglena gracilis. - Environ. Sci.-Nano 2: 594-602, 2015.

Li Y., Li W., Zhang H. et al.: Amplified light harvesting for enhancing Italian lettuce photosynthesis using water soluble silicon quantum dots as artificial antennas. - Nanoscale 12: 155-166, 2020.

Liang L., Tang H., Deng Z. et al.: Ag nanoparticles inhibit the growth of the bryophyte, Physcomitrella patens. - Ecotox. Environ. Safe. 164: 739-748, 2018.

Liu Y., Yue L., Wang C. et al:: Photosynthetic response mechanisms in typical $\mathrm{C}_{3}$ and $\mathrm{C}_{4}$ plants upon $\mathrm{La}_{2} \mathrm{O}_{3}$ nanoparticle exposure. - Environ. Sci.-Nano 7: 81-92, 2020.

Liu Y., Yue L., Wang Z., Xing B.: Processes and mechanisms of photosynthesis augmented by engineered nanomaterials. Environ. Chem. 16: 430-445, 2019.

Lizzi D., Mattiello A., Marchiol L.: Impacts of cerium oxide nanoparticles $\left(n \mathrm{CeO}_{2}\right)$ on crop plants: a concentric overview. In: Tripathi D.K., Ahmad P., Sharma S., Dubey N.K. (ed.): Nanomaterials in Plants, Algae and Microorganisms. Pp. 311324. Academic Press, London 2019.

Mahto R., Chatterjee N., Priya T., Singh R.K.: Nanotechnology and its role in agronomic crops. - In: Hasanuzzaman M. (ed.): Agronomic Crops. Pp. 605-636. Springer, Singapore 2019.

Majumdar S., Peralta-Videa J.R., Trujillo-Reyes J. et al.: Soil organic matter influences cerium translocation and physiological processes in kidney bean plants exposed to cerium oxide nanoparticles. - Sci. Total Environ. 569-570: 201-211, 2016.

Marusenko Y., Shipp J., Hamilton G.A. et al.: Bioavailability of nanoparticulate hematite to Arabidopsis thaliana. - Environ. Pollut. 74: 150-156, 2013.

Maswada H.F., Djanaguiraman M., Prasad P.V.V.: Seed treatment with nano-iron (III) oxide enhances germination, seeding growth and salinity tolerance of sorghum. - J. Agron. Crop Sci. 204: 577-587, 2018.

Matouke M.M., Elewa D.T., Abdullahi K.: Binary effect of titanium dioxide nanoparticles $\left(n \mathrm{TiO}_{2}\right)$ and phosphorus on microalgae (Chlorella ellipsoides Gerneck, 1907). - Aquat. Toxicol. 198: 40-48, 2018.

Mezacasa A.V., Queiroz A.M., Graciano D.E. et al.: Effects of gold nanoparticles on photophysical behaviour of chlorophyll and pheophytin. - J. Photoch. Photobio. A 389: 112252, 2020.

Middepogu A., Hou J., Gao X., Lin D.: Effect and mechanism of $\mathrm{TiO}_{2}$ nanoparticles on the photosynthesis of Chlorella pyrenoidosa. - Ecotox. Environ. Safe 161: 497-506, 2018. 
Mishra V., Mishra R.K., Dikshit A., Pandey A.C.: Interactions of nanoparticles with plants: an emerging prospective in the agriculture industry. - In: Ahmad P., Rasool S. (ed.): Emerging Technologies and Management of Crop Stress Tolerance. Pp. 159-180. Academic Press, Amsterdam 2014.

Missaoui T., Smiri M., Chmingui H., Hafiane A.: Effects of nanosized titanium dioxide on the photosynthetic metabolism of fenugreek (Trigonella foenum-graecum L.). - C. R. Biol. 340: 499-511, 2017.

Mohammadi H., Amani-Ghadim A.R., Matin A.A., Ghorbanpour M.: $\mathrm{Fe}^{0}$ nanoparticles improve physiological and antioxidative attributes of sunflower (Helianthus annuus) plants grown in soil spiked with hexavalent chromium. - 3 Biotech 10: 19, 2020.

Mohammadi M., Hatami M., Feghezadeh K., Ghorbanpour M.: Mitigating effect of nano-zerovalent iron, iron sulfate and EDTA against oxidative stress induced by chromium in Helianthus annuus L. - Acta Physiol. Plant. 40: 69, 2018.

Morelli E., Gabellieri E., Bonomini A. et al.: $\mathrm{TiO}_{2}$ nanoparticles in seawater: Aggregation and interactions with the green alga Dunaliella tertiolecta. - Ecotox. Environ. Safe. 148: 184-193, 2018.

Movafeghi A., Khataee A., Abedi M. et al.: Effects of $\mathrm{TiO}_{2}$ nanoparticles on the aquatic plant Spirodela polyrrhiza: evaluation of growth parameters, pigment contents and antioxidant enzyme activities. - J. Environ. Sci. 64: 130-138, 2018.

Nair P.M.G., Chung I.M.: Physiological and molecular level effects of silver nanoparticles exposure in rice (Oryza sativa L.) seedlings. - Chemosphere 112: 105-113, 2014.

Nam S.-H., Kwak J.I., An Y.-J.: Quantification of silver nanoparticle toxicity to algae in soil via photosynthetic and flow-cytometric analyses. - Sci. Rep.-UK 8: 292, 2018.

Nogueira P.F.M., Nakabayashi D., Zucolotto V.: The effects of graphene oxide on green algae Raphidocelis subcapitata. Aquat. Toxicol. 166: 29-35, 2015.

Ogunkunle C.O., Adegboye E.F., Okoro H.K. et al:: Effect of nanosized anatase $\mathrm{TiO}_{2}$ on germination, stress defense enzymes, and fruit nutritional quality of Abelmoschus esculentus (L.) Moench (okra). - Arab. J. Geosci. 13: 120, 2020.

Pagano L., Maestri E., Caldara M. et al.: Engineered nanomaterial activity at the organelle level: Impacts on the chloroplasts and mitochondria. - ACS Sustain. Chem. Eng. 6: 1256212579, 2018

Park S., Ahn Y.J.: Multi-walled carbon nanotubes and silver nanoparticles differentially affect seed germination, chlorophyll content, and hydrogen peroxide accumulation in carrot (Daucus carota L.). - Biocatal. Agric. Biotechnol. 8: 257262, 2016

Peharec Štefanić P., Cvjetko P., Biba R. et al.: Physiological, ultrastructural and proteomic responses of tobacco seedlings exposed to silver nanoparticles and silver nitrate. Chemosphere 209: 640-653, 2018.

Perez-de-Luque A.: Interaction of nanomaterials with plants: What do we need for real applications in agriculture? - Front. Env. Sci. 5: 12, 2017.

Pinto M., Soares C., Pinto A.S., Fidalgo F.: Phytotoxic effects of bulk and nano-sized $\mathrm{Ni}$ on Lycium barbarum L. grown in vitro - Oxidative damage and antioxidant response. Chemosphere 218: 507-516, 2019.

Pradhan S., Patra P., Mitra S. et al:: Copper nanoparticle $(\mathrm{CuNP})$ nanochain arrays with a reduced toxicity response: a biophysical and biochemical outlook on Vigna radiata. J. Agr. Food Chem. 63: 2606-2617, 2015.

Pullagurala V.L.R., Adisa I.O., Rawat S. et al.: ZnO nanoparticles increase photosynthetic pigments and decrease lipid peroxidation in soil grown cilantro (Coriandrum sativum). Plant Physiol. Bioch. 132: 120-127, 2018.

Qi M., Liu Y., Li T.: Nano- $\mathrm{TiO}_{2}$ improve the photosynthesis of tomato leaves under mild heat stress. - Biol. Trace Elem. Res. 156: 323-328, 2013.

Qian H., Peng X., Han X. et al.: Comparison of the toxicity of silver nanoparticles and silver ions on the growth of terrestrial plant model Arabidopsis thaliana. - J. Environ. Sci. 25: 1947 1956, 2013.

Rahayu I., Darmawan W., Zaini L.H., Prihatini E.: Characteristics of fast-growing wood impregnated with nanoparticles. J. Forestry Res. 31: 677-685, 2020.

Rahimi S., Hatami M., Ghorbanpour M.: Silicon-nanoparticle mediated changes in seed germination and vigor index of marigold (Calendula officinalis L.) compared to silicate under PEG-induced drought stress. - Gesunde Pflanzen, 2021.

Rajput V., Minkina T., Fedorenko A. et al.: Toxicity of copper oxide nanoparticles on spring barley (Hordeum sativum distichum). - Sci. Total Environ. 645: 1103-1113, 2018.

Rani P.U., Yasur J., Loke K.S., Dutta D.: Effect of synthetic and biosynthesized silver nanoparticles on growth, physiology and oxidative stress of water hyacinth: Eichhornia crassipes (Mart) Solms. - Acta Physiol. Plant. 38: 58, 2016.

Rastogi A., Tripathi D.K., Yadav S. et al.: Application of silicon nanoparticles in agriculture. -3 Biotech 9: 90, 2019a.

Rastogi A., Zivcak M., Tripathi D.K. et al.: Phytotoxic effect of silver nanoparticles in Triticum aestivum: Improper regulation of photosystem I activity as the reason for oxidative damage in the chloroplast. - Photosynthetica 57: 209-216, 2019 b.

Rawat S., Adisa I.O., Wang Y. et al.: Differential physiological and biochemical impacts of nano vs micron $\mathrm{Cu}$ at two phenological growth stages in bell pepper (Capsicum annuum) plant. - NanoImpact 14: 100161, 2019.

Ren H.Y., Dai Y.Q., Kong F. et al.: Enhanced microalgal growth and lipid accumulation by addition of different nanoparticles under xenon lamp illumination. - Bioresource Technol. 297: 122409, 2020.

Rico C.M., Majumdar S., Duarte-Gardea M. et al.: Interaction of nanoparticles with edible plants and their possible implications in the food chain. - J. Agr. Food Chem. 59: 3485-3498, 2011.

Röhder L.A., Brandt T., Sigg L., Behra R.: Influence of agglomeration of cerium oxide nanoparticles and speciation of cerium(III) on short term effects to the green algae Chlamydomonas reinhardtii. - Aquat Toxicol. 152: 121-130, 2014.

Rossi L., Zhang W., Lombardini L., Ma X.: The impact of cerium oxide nanoparticles on the salt stress responses of Brassica napus L. - Environ. Pollut. 219: 28-36, 2016.

Rossi L., Zhang W., Ma X.: Cerium oxide nanoparticles alter the salt stress tolerance of Brassica napus L. by modifying the formation of root apoplastic barriers. - Environ. Pollut. 229: 132-138, 2017.

Salama D.M., Osman S.A., Abd El-Aziz M. et al.: Effect of zinc oxide nanoparticles on the growth, genomic DNA, production and the quality of common dry bean (Phaseolus vulgaris). Biocatal. Agric. Biotechnol. 18: 101083, 2019.

Salama H.M.H.: Effects of silver nanoparticles in some crop plants, common bean (Phaseolus vulgaris L.) and corn (Zea mays L.). - Int. J. Biotechnol. Res. 3: 190-197, 2012.

Samadi N., Yahyaabadi S., Rezayatmand Z.: Effect of $\mathrm{TiO}_{2}$ and $\mathrm{TiO}_{2}$ nanoparticle on germination, root and shoot length and photosynthetic pigments of Mentha piperita. - Int. J. Plant Soil Sci. 3: 408-418, 2014.

Samadi S., Saharkhiz M.J., Azizi M. et al.: Multi-walled carbon nanotubes stimulate growth, redox reactions and biosynthesis 
of antioxidant metabolites in Thymus daenensis Celak. in vitro. - Chemosphere 249: 126069, 2020.

Samadi S., Saharkhiz M.J., Azizi M. et al.: Single-wall carbon nano tubes (SWCNTs) penetrate Thymus daenensis Celak. plant cells and increase secondary metabolite accumulation in vitro. - Ind. Crop. Prod. 165: 113424, 2021.

Sami F., Siddiqui H., Hayat S.: Impact of silver nanoparticles on plant physiology: A critical review. - In: Hayat S., Pichtel J., Faizan M., Fariduddin Q. (ed.): Sustainable Agriculture Reviews 41. Pp. 111-127. Springer, Cham 2020.

Santos S.M.A., Dinis A.M., Rodrigues D.M.F. et al.: Studies on the toxicity of an aqueous suspension of C60 nanoparticles using a bacterium (gen. Bacillus) and an aquatic plant (Lemna gibba) as in vitro model systems. - Aquat. Toxicol. 142-143: 347-354, 2013.

Schwab F., Bucheli T.D., Camenzuli L. et al.: Diuron sorbed to carbon nanotubes exhibits enhanced toxicity to Chlorella vulgaris. - Environ. Sci. Technol. 47: 7012-7019, 2013.

Schwab F., Zhai G., Kern M. et al.: Barriers, pathways and processes for uptake, translocation and accumulation of nanomaterials in plants - Critical review. - Nanotoxicology 10: $257-278,2015$.

Sendra M., Moreno-Garrido I., Blasco J., Araújo C.V.M.: Effect of erythromycin and modulating effect of $\mathrm{CeO}_{2}$ NPs on the toxicity exerted by the antibiotic on the microalgae Chlamydomonas reinhardtii and Phaeodactylum tricornutum. - Environ. Pollut. 242: 357-366, 2018.

Serag M.F., Kaji N., Gaillard C. et al.: Trafficking and subcellular localization of multiwalled carbon nanotubes in plant cells. ACS Nano 5: 493-499, 2011.

Sharifi-Rad J., Quispe C., Butnariu M. et al.: Chitosan nanoparticles as a promising tool in nanomedicine with particular emphasis on oncological treatment. - Cancer Cell Int. 21: 318, 2021.

Sharma P., Bhatt D., Zaidi M.G.H. et al.: Silver nanoparticlemediated enhancement in growth and antioxidant status of Brassica juncea. - Appl. Biochem. Biotech. 167: 2225-2233, 2012.

Sharma S., Uttam K.N.: Rapid analyses of stress of copper oxide nanoparticles on wheat plants at an early stage by laser induced fluorescence and attenuated total reflectance Fourier transform infrared spectroscopy. - Vib. Spectrosc. 92: 135150, 2017.

Shaw A.K, Ghosh S., Kalaji H.M. et al.: Nano-CuO stress induced modulation of antioxidative defense and photosynthetic performance of Syrian barley (Hordeum vulgare L.). Environ. Exp. Bot. 102: 37-47, 2014.

Sheikhalipour M., Esmaielpour B., Behnamian M. et al.: Chitosan-selenium nanoparticle (Cs-Se NP) foliar spray alleviates salt stress in bitter melon. - Nanomaterials 11: 684, 2021.

Siddiqui M.H., Al-Whaibi M.H., Faisal M., Al Sahli A.A.: Nano-silicon dioxide mitigates the adverse effects of salt stress on Cucurbita pepo L. - Environ. Toxicol. Chem. 33: 2429-2437, 2014.

Singh A., Singh N.B., Hussain I. et al.: Green synthesis of nano zinc oxide and evaluation of its impact on germination and metabolic activity of Solanum lycopersicum. - J. Biotechnol. 233: 84-94, 2016.

Singh T., Shukla S., Kumar P. et al.: Application of nanotechnology in food science: Perception and overview. - Front. Microbiol. 8: 1501, 2017.

Sousa C.A., Soares M.H.V.M., Soares E.V.: Toxic effects of nickel oxide $(\mathrm{NiO})$ nanoparticles on the freshwater alga Pseudokirchneriella subcapitata. - Aquat. Toxicol. 204: 8090, 2018.
Spinoso-Castillo J.L., Chavez-Santoscoy R., Bogdanchikova N. et al.: Antimicrobial and hormetic effects of silver nanoparticles on in vitro regeneration of vanilla (Vanilla planifolia Jacks. ex Andrews) using a temporary immersion system. - Plant Cell Tiss. Org. Cult. 129: 195-207, 2017.

Suriyaprabha R., Karunakaran G., Yuvakkumar R. et al.: Growth and physiological responses of maize (Zea mays L.) to porous silica nanoparticles in soil. - J. Nanopart. Res. 14: 1294, 2012.

Swapna M.S., Raj V., Devi H.V.S., Sankararaman S.: Optical emission diagnosis of carbon nanoparticle-incorporated chlorophyll for sensing applications. - Photoch. Photobio. Sci. 18: 1382-1388, 2019.

Swift T.A., Oliver T.A.A., Galan M.C., Whitney M.: Functional nanomaterials to augment photosynthesis: evidence and considerations for their responsible use in agricultural applications. - Interface Focus 9: 20180048, 2019.

Tan W., Deng C., Wang Y. et al.: Interaction of nanomaterials in secondary metabolites accumulation, photosynthesis, and nitrogen fixation in plant systems. - Compr. Anal. Chem. 84: 55-74, 2019.

Tang Y., Li S., Lu Y. et al.: The influence of humic acid on the toxicity of nano- $\mathrm{ZnO}$ and $\mathrm{Zn}^{2+}$ to the Anabaena sp. - Environ. Toxicol. 30: 895-903, 2015.

Tao X., Yu Y., Fortner J.D. et al.: Effects of aqueous stable fullerene nanocrystal $\left(\mathrm{nC}_{60}\right)$ on Scenedesmus obliquus: evaluation of the sub-lethal photosynthetic responses and inhibition mechanism. - Chemosphere 122: 162-167, 2015.

Tayemeh M.B., Esmailbeigi M., Shirdel I. et al.: Perturbation of fatty acid composition, pigments, and growth indices of Chlorella vulgaris in response to silver ions and nanoparticles: A new holistic understanding of hidden ecotoxicological aspect of pollutants. - Chemosphere 238: 124576, 2020.

Thapa M., Singh M., Ghosh C.K. et al.: Zinc sulphide nanoparticle (nZnS): A novel nano-modulator for plant growth. - Plant Physiol. Bioch. 142: 73-83, 2019.

Tian H., Ghorbanpour M., Kariman K.: Manganese oxide nanoparticle-induced changes in growth, redox reactions and elicitation of antioxidant metabolites in deadly nightshade (Atropa belladonna L.). - Ind. Crop. Prod. 126: 403-414, 2018.

Tighe-Neira R., Carmora E., Recio G. et al.: Metallic nanoparticles influence the structure and function of the photosynthetic apparatus in plants. - Plant Physiol. Bioch. 130: 408-417, 2018.

Tkalec M., Cvjetko P., Biba R. et al.: Impact of silver nanoparticles on photosynthesis in tobacco plants. - Toxicol. Lett. 280: S184, 2017.

Tombuloglu H., Slimani Y., Tombuloglu G. et al.: Uptake and translocation of magnetite $\left(\mathrm{Fe}_{3} \mathrm{O}_{4}\right)$ nanoparticles and its impact on photosynthetic genes in barley (Hordeum vulgare L.). - Chemosphere 226: 110-122, 2019.

Torrent L., Iglesias M., Marguí E. et al.: Uptake, translocation and ligand of silver in Lactuca sativa exposed to silver nanoparticles of different size, coatings and concentration. J. Hazard. Mater. 384: 121201, 2020.

Torres R., Diz V.E., Lagorio M.G.: Effects of gold nanoparticles on the photophysical and photosynthetic parameters of leaves and chloroplasts. - Photoch. Photobio. Sci. 17: 505-516, 2018.

Tripathi A., Liu S., Singh P.K. et al.: Differential phytotoxic responses of silver nitrate $\left(\mathrm{AgNO}_{3}\right)$ and silver nanoparticle (AgNps) in Cucumis sativus L. - Plant Gene 11: 255-264, 2017a.

Tripathi D.K., Singh S., Singh S. et al.: Nitric oxide alleviates silver nanoparticles (AgNps)-induced phytotoxicity in Pisum sativum seedlings. - Plant Physiol. Bioch. 110: 167-177, $2017 \mathrm{~b}$. 
Tripathi D.K., Singh S., Singh V.P. et al.: Silicon nanoparticles more effectively alleviated UV-B stress than silicon in wheat (Triticum aestivum) seedlings. - Plant Physiol. Bioch. 110: 70-81, 2017c.

Ulhassan Z., Ali S., Gill R.A. et al.: Comparative orchestrating response of four oilseed rape (Brassica napus) cultivars against the selenium stress as revealed by physiochemical, ultrastructural and molecular profiling. - Ecotox. Environ. Safe. 161: 634-647, 2018

Ulhassan Z., Gill R.A., Ali S. et al.: Dual behavior of selenium: Insights into physio-biochemical, anatomical and molecular analyses of four Brassica napus cultivars. - Chemosphere 225: 329-341, 2019a.

Ulhassan Z., Huang Q., Gill R.A. et al.: Protective mechanisms of melatonin against selenium toxicity in Brassica napus: insights into physiological traits, thiol biosynthesis and antioxidant machinery. - BMC Plant Biol. 19: 507, $2019 \mathrm{~b}$.

Večeřová K., Večeřa Z., Dočekal B. et al.: Changes of primary and secondary metabolites in barley plants exposed to $\mathrm{CdO}$ nanoparticles. - Environ. Pollut. 218: 207-218, 2016.

Verma S.K., Das A.K., Gantait S. et al.: Applications of carbon nanomaterials in the plant system: a perspective view on the pros and cons. - Sci. Total Environ. 667: 485-499, 2019.

Wang A., Jin Q., Xu X. et al.: High-throughput screening for engineered nanoparticles that enhance photosynthesis using mesophyll protoplasts. - J. Agr. Food Chem. 68: 3382-3389, 2020.

Wang C., Zhang H., Ruan L. et al.: Bioaccumulation of ${ }^{13} \mathrm{C}$-fullerenol nanomaterials in wheat. - Environ. Sci.-Nano 3: 799-805, 2016

Wang H., Zhang M., Song Y. et al.: Carbon dots promote the growth and photosynthesis of mung bean sprouts. - Carbon 136: 94-102, 2018.

Winkelmann K., Bernas L., Swiger B., Brown S.: Measurement of chlorophyll loss due to phytoremediation of $\mathrm{Ag}$ nanoparticles in the first-year laboratory. - J. Chem. Educ. 94: 751-757, 2017.

Wong M.H., Misra R.P., Giraldo J.P. et al.: Lipid exchange envelope penetration (LEEP) of nanoparticles for plant engineering: a universal localization mechanism. - Nano Lett. 16: 1161-1172, 2016.

Wu H., Lin Z.: Recent advances in nano-enabled agriculture for improving plant performance. - Crop J., 2021. (In press)

Wu H., Shabala L., Shabala S., Giraldo J.P.: Hydroxyl radical scavenging by cerium oxide nanoparticles improves Arabidopsis salinity tolerance by enhancing leaf mesophyll potassium retention. - Environ. Sci.-Nano 5: 1567-1583,
2018.

Wu H., Tito N., Giraldo J.P.: Anionic cerium oxide nanoparticles protect plant photosynthesis from abiotic stress by scavenging reactive oxygen species. - ACS Nano 11: 11283-11297, 2017.

$\mathrm{Xu}$ X., Mao X., Zhuang J. et al.: PVA-coated fluorescent carbon dot nanocapsules as an optical amplifier for enhanced photosynthesis of lettuce. - ACS Sustain. Chem. Eng. 8: 3938-3949, 2020.

Yang F., Liu C., Gao F. et al.: The improvement of spinach growth by nano-anatase $\mathrm{TiO}_{2}$ treatment is related to nitrogen photoreduction. - Biol. Trace Elem. Res. 119: 77-88, 2007.

Yasmeen F., Raja N.I., Ilyas N., Komatsu S.: Quantitative proteomic analysis of shoot in stress tolerant wheat varieties on copper nanoparticle exposure. - Plant Mol. Biol. Rep. 36: 326-340, 2018

Younes N.A., Dawood M.F.A., Wardany A.A.: Biosafety assessment of graphene nanosheets on leaf ultrastructure, physiological and yield traits of Capsicum annuum L. and Solanum melongena L. - Chemosphere 228: 318-327, 2019.

Zahedi S.M., Hosseini M.S., Meybodi N.D.H. et al.: Foliar application of selenium and nano-selenium affects pomegranate (Punica granatum cv. Malase Saveh) fruit yield and quality. - S. Afr. J. Bot. 124: 350-358, 2019.

Zhai G., Walters K.S., Peate D.W. et al.: Transport of gold nanoparticles through plasmodesmata and precipitation of gold ions in woody poplar. - Environ. Sci. Technol. Lett. 1: 146-151, 2014.

Zhang L., Goswami N., Xie J. et al.: Unraveling the molecular mechanism of photosynthetic toxicity of highly fluorescent silver nanoclusters to Scenedesmus obliquus. - Sci. Rep.-UK 7: 16432, 2017.

Zhao L., Lu L., Wang A. et al.: Nano-biotechnology in agriculture: Use of nanomaterials to promote plant growth and stress tolerance. - J. Agr. Food Chem. 68: 1935-1947, 2020.

Zhao L., Peralta-Videa J.R., Peng B. et al.: Alginate modifies the physiological impact of $\mathrm{CeO}_{2}$ nanoparticles in corn seedlings cultivated in soil. - J. Environ. Sci. 26: 382-389, 2014.

Zhao L., Sun Y., Hernandez-Viezcas J.A. et al.: Monitoring the environmental effects of $\mathrm{CeO}_{2}$ and $\mathrm{ZnO}$ nanoparticles through the life cycle of corn (Zea mays) plants and in situ $\mu$-XRF mapping of nutrients in kernels. - Environ. Sci. Technol. 49: 2921-2928, 2015.

Zhao L., Zhang H., White J.C. et al:: Metabolomics reveals that engineered nanomaterial exposure in soil alters both soil rhizosphere metabolite profiles and maize metabolic pathways. - Environ. Sci.-Nano 6: 1716-1727, 2019.

(C) The authors. This is an open access article distributed under the terms of the Creative Commons BY-NC-ND Licence. 